1

2

3

4

5

6

Article

\title{
Synthesis and biological evaluation of 3-substituted-
} 4-(quinoxalin-6-yl) pyrazoles as selective ALK5 inhibitors

\author{
Li-Min Zhao', Zhen Guo', Yi-Jie Xue, Jun Zhe Min, Wen-Jing Zhu, Xiang-Yu Li, Hu-Ri Piao, \\ Cheng Hua Jin* \\ College of Pharmacy, Yanbian University, 977 Gongyuan Road, Yanji, Jilin Province 133002, PR China \\ ${ }^{*}$ Corresponding author: E-mail: jinchenghua@ybu.edu.cn; Tel: + 86-433-243-6942 \\ + These authors contributed equally to this work.
}

\begin{abstract}
The transforming growth factor- $\beta$ (TGF- $\beta$ ), in which overexpression have been associated with various diseases, has become an attractive molecular target for the treatment of cancers. Three series of 3-substituted-4-(quinoxalin-6-yl) pyrazoles 14a-h, 15a-h, 16a-h, 22a, 22b, 22d, 23a, 23b, 23d, 24b, and 24d were synthesized and evaluated for their activin receptor-like kinase 5 (ALK5) and p38 $\alpha$ mitogen activated protein (MAP) kinase inhibitory activity in an enzymatic assays. Among these compounds, the most active compound 16f inhibited ALK5 phosphorylation with an IC 50 value of $0.28 \mu \mathrm{M}$, with $98 \%$ inhibition at $10 \mu \mathrm{M}$. Compound $\mathbf{1 6 f}$ also had good selectivity index of $>35$ against p38 $\alpha$ MAP kinase, with 9.0-fold more selective than clinical candidate, compound 3 (LY-2157299). Molecular docking study was performed to identify the mechanism of action of the synthesized compounds and their good binding interactions were observed. ADMET prediction of good active compounds showed that these ones possess good pharmacokinetics and drug-likeness behavior.
\end{abstract}

Keywords: ALK5 inhibitor; TGF- $\beta$; kinase assay; selectivity; docking 


\section{Introduction}

Transforming growth factor- $\beta$ (TGF- $\beta$ ) superfamily members have a wide range of cellular functions, including cell proliferation, differentiation, adhesion, migration and apoptosis [1]. Moreover, TGF- $\beta$ superfamily members are proteins with similar structures, including TGF- $\beta$ s, activins, bone morphogeneticproteins (BMPs), growth and differentiation factors. TGF- $\beta$ plays a crucial role in initiation and progression of fibrosis in various tissues such as the heart [2], lung [3], liver [4] and kidney [5]. TGF- $\beta$ s are composed of five homogeneous isomers with highly homologous amino acid sequences, TGF- $\beta 1$, TGF- $\beta 2$, TGF- $\beta 3$, TGF- $\beta 4$, and TGF- $\beta 5$, though only the first three exist in humans. Among these isoforms, TGF- $\beta 1$ is the prototype and major isoform of this family. TGF- $\beta$ conducts signaling through two distinct serine and threonine kinase receptors as TGF- $\beta$ type I (activin receptor-like kinase 5, ALK5) and type II receptors [6]. ALK5 is activated by the combination of TGF- $\beta$ and the type II receptor in the juxtamembrane GS domain, stimulating its kinase activity. The activated ALK5 spread the signals through phosphorylation of Smad2 and Smad3, and followed by binding with Smad4 to form complexes. These Smad complexes will translocate into the nuclei, where they regulate the target gene transcription such as cell differentiation, proliferation, apoptosis, migration, and extracellular matrix production [1]. Nevertheless, overexpression of TGF- $\beta$ signaling was shown to attenuate various human diseases such as hematological malignancy [7], cancer [8], and pancreatic diseases [9].

For this reason, many small molecule ALK5 inhibitors, such as compounds 1 (SB-505124) [10], 2 (SD-208) [11], 3 (LY-2157299) [12], and 4 (EW-7197) [13] were synthesized at major research institutions. These compounds inhibited ALK5 autophosphorylation and TGF- $\beta$-induced transcription of extracellular matrix genes at sub-micromolar concentrations in reporter assays, as shown in Figure 1. Among them, clinical candidates, compounds 3 and 4 have progressed to Phase II and Phase I trials as antitumor agents, respectively.

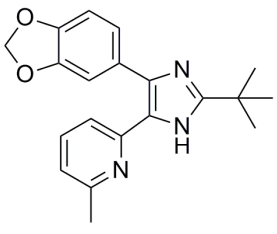

1 (SB-505124)

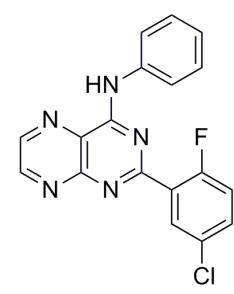

2 (SD-208)

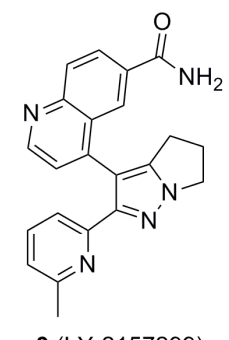

$3($ LY-2157299)

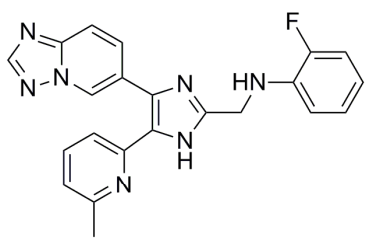

$4(E W-7197)$<smiles>[R]c1cccc(NC(=O)Cn2cc(-c3ccc4nc([R])c([R])nc4c3)c(-c3cccc(C)n3)n2)c1</smiles>

Figure 1. ALK5 inhibitors under development.

We previously showed that a series of compounds, denoted as $\mathbf{5}$, containing the quinoxaline moiety, except for the 2,3-dimethyl substituted analogs, showed significant ALK5 inhibition in an enzymatic assay [14]. This series of compounds was selective for ALK5, compared with p38 $\alpha$ MAP kinase. The most active compound inhibited ALK5 phosphorylation with an $\mathrm{IC}_{50}$ value of $0.013 \mu \mathrm{M}$ and a selectivity index of $>77$ against p38 $\alpha$ MAP kinase.

Tojo et al. described a novel class of ALK5 inhibitors possessing a thioamide linkage between the phenyl and pyrazole rings [15]. Among these, compound 6 (A-83-01) inhibited ALK5 with an IC50 value of $0.012 \mu \mathrm{M}$. Although including a thioamide linkage between the phenyl and pyrazole ring distinctly increased ALK5 inhibitory activity, as previously shown [16], the thioamide linkage was rather unstable and was slowly cleaved, to release a pyrazole ring, during long-term storage. 
It was reported that compounds containing a thiazole and pyrimidine moiety have useful biological activities, such as antibacterial [17], anticancer [18,19], antiviral [20], anti-inflammatory [21], and antimalarial properties [22].

Based on this finding and previous research, we tried to replace the thioamide linkage with a chemically stable thioamidomethylene linkage and, thus, designed compounds $\mathbf{1 6 a}-\mathbf{h}, \mathbf{2 4 b}$, and $\mathbf{2 4 d}$. To compare the effects of the thioamidomethylene linkage in $\mathbf{1 6} \mathbf{a}-\mathbf{h}, \mathbf{2 4 b}$, and $\mathbf{2 4 d}$ on ALK5 inhibitory activity, their counterpart derivatives $\mathbf{1 4} \mathbf{a}-\mathbf{h}, \mathbf{1 5} \mathbf{a}-\mathbf{h}, \mathbf{2 2} \mathbf{b}, \mathbf{2 2 d}, \mathbf{2 3} \mathbf{b}$, and $\mathbf{2 3 d}$ possessing an amidomethylene linkage, were also designed. Previously, we showed that the methyl group of 6methylpyridine in compound 4 formed hydrophobic interactions with the aromatic ring of Tyr249 and that the nitrogen atom of the same moiety formed a water-mediated hydrogen bonding network with the side chains of Tyr249 and Glu245 and the backbone of Asp351 [13]. To examine whether the capability of the nitrogen atom of the 6-methylpyridine moiety as an H-bond acceptor would be increased by other substitutions, we introduced 6-(dimethylamino)pyridin-2-yl, 4-methylthiazol-2yl, and pyrimidin-4-yl groups, instead of the 6-methylpyridine moiety, in 5 series compound. The target compounds 14b-d, 14f-h, 15b-d, 15f-h, 16b-d, 16a-h, 22b, 22d, 23b, 23d, 24b, and 24d each possess a substituent, either $o-\mathrm{F}, m-\mathrm{F}$ or $m-\mathrm{CN}$, in the phenyl ring because these were previously found to be most beneficial for ALK5 inhibitory activity and selectivity [13].

\section{Results and discussion}

\subsection{Synthesis}

The 3-(6-(dimethylamino)pyridin-2-yl)-4-(quinoxalin-6-yl)pyrazoles $\quad \mathbf{1 4 a - d}$ and 3-(4methylthiazol-2-yl)-4-(quinoxalin-6-yl)pyrazoles $\mathbf{1 4} \mathbf{e}-\mathbf{h}$ were synthesized as shown in Scheme 1 . The 6-(dimethylamino)picolinaldehyde (8) [23] and 4-methylthiazole-2-carbaldehyde (9) were treated with aniline and diphenyl phosphite in $i-\mathrm{PrOH}$ at room temperature to give the (phenylamino)methylphosphonates 10a and 10b in $90 \%$ and $70 \%$ yields, respectively. Coupling of the 10a and 10b with quinoxaline-6-carbaldehyde [24] in a mixture of THF and $i-\mathrm{PrOH}(4: 1)$ at room temperature in the presence of $\mathrm{Cs}_{2} \mathrm{CO}_{3}$, followed by hydrolysis with $1 \mathrm{~N} \mathrm{HCl}$, produced the corresponding monoketones $\mathbf{1 1 a}$ and $\mathbf{1 1 b}$ in $71 \%$ and $52 \%$ yields, respectively [14]. Treatment of 11a and $\mathbf{1 1 b}$ with $N, N$-dimethylformamide dimethyl acetal (DMF•DMA) in $N, N$-dimethylformamide $(\mathrm{DMF})$ at $80^{\circ} \mathrm{C}$, followed by cyclization with hydrazine monohydrate in absolute EtOH, produced the pyrazoles $\mathbf{1 2} \mathbf{a}$ and $\mathbf{1 2} \mathbf{b}$ in $68 \%$ and $71 \%$ yields, respectively [25]. The pyrazoles $\mathbf{1 2 a}$ and $\mathbf{1 2 b}$ were alkylated with 2-chloro- $N$-phenylacetamide (13a) [26], 2-chloro- $N$-(2-fluorophenyl)acetamide (13b), 2-chloro- $N$-(3-fluorophenyl)acetamide (13c) or 2-chloro- $N$-(3-cyanophenyl)acetamide (13d) [27] in the presence of $\mathrm{NaH}$ in anhydrous DMF to yield the target compounds $\mathbf{1 4} \mathbf{a}-\mathbf{h}$ and their positional isomers 15a-h in $40 \%-81 \%$ and $7 \%-15 \%$ yields, respectively. The positional isomers were separated by column chromatography and their structures were confirmed by nuclear overhauser enhancement (NOE) experiments. In NOE experiments, irradiation of the methylene protons of compound 14a at $\delta 5.06$ gave an enhancement of the proton $H-5$ in the pyrazole ring at $\delta 7.80$, while irradiation of the methylene protons of compound 15a at $\delta 5.17$ gave no enhancement of the proton $H-5$ in the pyrazole ring at $\delta 8.02$, confirming the respective alkylation positions. 
Thionation of compounds $\mathbf{1 4 a} \mathbf{a} \mathbf{h}$ with Lawesson's reagent in anhydrous 1,2-dimethoxyethane

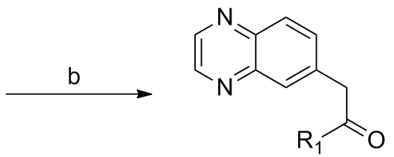

11a: $R_{1}=6-($ dimethylamino)pyridin-2-yl $(71 \%)$

$(70 \%) \quad 11 \mathrm{~b}: \mathrm{R}_{1}=4$-methylthiazol-2-yl

$(52 \%)$ 14a: $R_{1}=6$-(diemthylamino)pyridin-2-yl, $\mathrm{R}_{2}=\mathrm{H}$ 14b: $R_{1}=6$-(dimethylamino)pyridin-2-yl, $R_{2}=2-F \quad(40 \%)$ 14c: $R_{1}=6$-(dimethylamino)pyridin-2-yl, $R_{2}=3-F \quad(50 \%)$ 14d: $R_{1}=6$-(dimethylamino)pyridin-2-yl, $R_{2}=3-C N(45 \%)$ 14e: $R_{1}=4$-methylthiazol-2-yl, $\quad \mathrm{R}_{2}=\mathrm{H} \quad(65 \%)$ 14f: $\mathrm{R}_{1}=4$-methylthiazol-2-yl, $\quad \mathrm{R}_{2}=2-\mathrm{F} \quad(70 \%)$

$\begin{array}{ll}\text { 14g: } R_{1}=4-\text { methylthiazol-2-yl, } & \mathrm{R}_{2}=3-\mathrm{F} \quad(81 \%) \\ \text { 14h: } \mathrm{R}_{1}=4 \text {-methylthiazol-2-yl, } & \mathrm{R}_{2}=3-\mathrm{CN}(74 \%)\end{array}$<smiles>[R][R]c1ccccc1NC(=O)Cn1cc(-c2ccc3nccnc3c2)c([R7])n1</smiles>

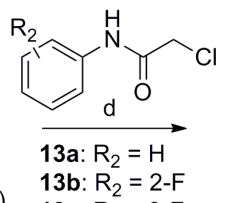

13c: $R_{2}=3-F$

13d: $R_{2}=3-C N$

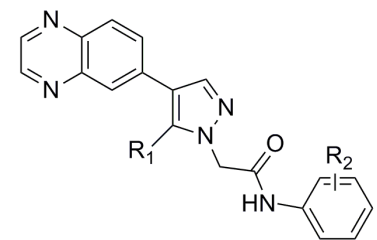

15a: $R_{1}=6$-(diemthylamino)pyridin-2-yl, $R_{2}=H \quad(10 \%)$ 15b: $R_{1}=6$-(dimethylamino)pyridin-2-yl, $R_{2}=2-F \quad(13 \%)$ 15c: $R_{1}=6$-(dimethylamino)pyridin-2-yl, $R_{2}=3-F \quad(15 \%)$ 15d: $R_{1}=6$-(dimethylamino)pyridin-2-yl, $R_{2}=3-C N(14 \%)$ 15e: $\mathrm{R}_{1}=4$-methylthiazol-2-yl, $\quad \mathrm{R}_{2}=\mathrm{H} \quad(8 \%)$ 15f: $R_{1}=4-$ methylthiazol-2-yl, $\quad R_{2}=2-F \quad(7 \%)$ 15g: $\mathrm{R}_{1}=4$-methylthiazol-2-yl, $\quad \mathrm{R}_{2}=3-\mathrm{F} \quad(7 \%)$ 15h: $R_{1}=4-$ methylthiazol-2-yl, $\quad \mathrm{R}_{2}=3-\mathrm{CN} \quad(9 \%)$

Scheme 1. Synthesis of target compounds $\mathbf{1 4 a}-\mathbf{h}$ and $\mathbf{1 5} \mathbf{a}-\mathbf{h}$. Reagents and conditions: (a) aniline, $(\mathrm{PhO})_{2} \mathrm{P}(\mathrm{O}) \mathrm{H}, \mathrm{rt}, 4 \mathrm{~h}$; (b) (i) quinoxaline-6-carbaldehyde, $\mathrm{Cs}_{2} \mathrm{CO}_{3}, \mathrm{rt}, 16 \mathrm{~h}$; (ii) $1 \mathrm{~N} \mathrm{HCl}, 1 \mathrm{~h}$; (c) (i) $\mathrm{DMF} \bullet \mathrm{DMA}, 80^{\circ} \mathrm{C}, 2 \mathrm{~h}$; (ii) $\mathrm{N}_{2} \mathrm{H}_{4} \cdot \mathrm{H}_{2} \mathrm{O}$, EtOH, reflux, 4 h; (d) $\mathrm{NaI}$ (cat.), $\mathrm{NaH}, \mathrm{rt}, 2$ h. (DME) at $85^{\circ} \mathrm{C}$ produced the thioamides 16a-h in 37\%-89\% yields as shown in Scheme 2.

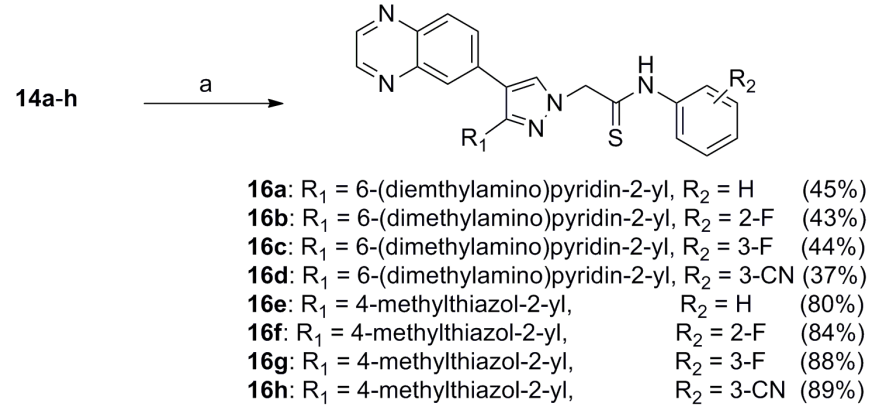

Scheme 2. Synthesis of compounds 16a-h. Reagents and conditions: (a) Lawesson's reagent, $85^{\circ} \mathrm{C}, 12$ h.

To increase binding sites with key proteins, the 3-(pyrimidin-4-yl)-4-(quinoxalin-6-yl)pyrazoles 22a, 22b, 22d was synthesized as shown in Scheme 3. Pyrimidine-4-carbaldehyde (17) [28] was synthesized from commercially available 1,1-dimethoxyacetone and $N, N$-dimethylformamide diemthyl acetal via 3 steps. Compound 20 was synthesized from compound $\mathbf{1 7}$ via 3 steps in the same reaction condition as described in Scheme 1. The pyrazole $\mathbf{2 0}$ was further alkylated with substituted phenylacetamides $\mathbf{2 1 a}, \mathbf{2 1} \mathbf{b}$ or $\mathbf{2 1 d}$ in the presence of $\mathrm{NaH}$ in anhydrous DMF to yield the target compounds 22a, 22b, 22d and their positional isomers 23a, 23b, 23d in 58\%-65\% and 7\%-13\% yields, respectively. And these positional isomers were also separated by column chromatography and their structures were confirmed by NOE experiments, as shown in Scheme 3. Similarly, the thioamide compounds $\mathbf{2 4 b}$ and $\mathbf{2 4 d}$ were synthesized from $\mathbf{2 2 b}$ and $\mathbf{2 2 d}$ in the same reaction condition as described in Scheme 2, respectively, as shown in Scheme 4. As expected, all synthesized target compounds were quite stable during long-term storage at room temperature. 
<smiles>[R]c1cccc(NC(=O)Cn2cc(-c3ccc4nccnc4c3)c(-c3ccncn3)n2)c1</smiles>

22a: $R=$ pyrimidin-4-yl, $R=H \quad(61 \%)$
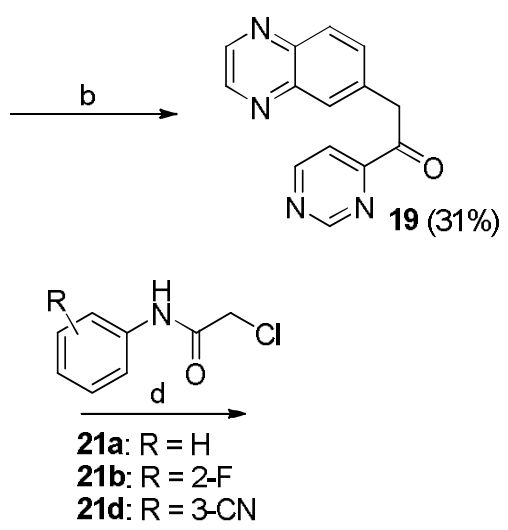

Scheme 3. Sythesis of compounds 22a, 22b, 22d, 23a, 23b, and 23d. Reagents and conditions: (a) aniline, $(\mathrm{PhO})_{2} \mathrm{P}(\mathrm{O}) \mathrm{H}, \mathrm{rt}, 4 \mathrm{~h}$; (b) (i) quinoxaline-6-carbaldehyde, $\mathrm{Cs}_{2} \mathrm{CO}_{3}, \mathrm{rt}, 16 \mathrm{~h}$; (ii) $1 \mathrm{~N} \mathrm{HCl}, 1 \mathrm{~h}$; (c) (i) $\mathrm{DMF} \bullet \mathrm{DMA}, 80^{\circ} \mathrm{C}, 2 \mathrm{~h}$; (ii) $\mathrm{N}_{2} \mathrm{H}_{4} \cdot \mathrm{H}_{2} \mathrm{O}, \mathrm{EtOH}$, reflux, 4 h; (d) $\mathrm{NaI}$ (cat.), $\mathrm{NaH}, \mathrm{rt}, 2 \mathrm{~h}$.

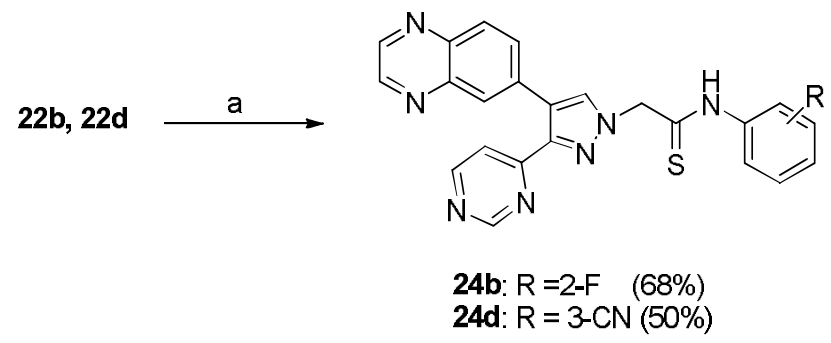

Scheme 4. Synthesis of compounds $24 \mathrm{~b}$ and $24 \mathrm{~d}$. Reagents and conditions: (a) Lawesson's reagent, $85^{\circ} \mathrm{C}, 12 \mathrm{~h}$.

\subsection{Residual activity in an enzymatic assay}

To investigate whether compounds $\mathbf{1 4 a}-\mathbf{h}, \mathbf{1 5} \mathbf{a}-\mathbf{h}$, and $\mathbf{1 6} \mathbf{a}-\mathbf{h}$ would inhibit ALK5, a kinase assay for preliminary screening was performed using the purified human ALK5 kinase domain produced in Sf9 insect cells and compounds at $10 \mu \mathrm{M}$. Compound 3 (LY-2157299) was used as a positive control. All compounds with a 4-methylthiazol-2-yl moiety (14e-h, 15e-h, and 16e-h) showed potent ALK5 inhibition activity (27\%-98\%), whereas those with a 6-(dimethylamino)pyiridin-2-yl moiety (14a-d, 15a-d, and 16a-d) showed moderate ALK5 inhibition activity (5\%-71\%), was reported in Table1.

The amides 14a-d (5\%-63\%) and 14e-h (95\%-97\%) showed more potent ALK5 inhibition than their respective positional isomers, $\mathbf{1 5 a}-\mathbf{d}(5 \%-13 \%)$ and $\mathbf{1 5} \mathbf{e}-\mathbf{h}(27 \%-54 \%)$, respectively. Among compounds containing a 6-(dimethylamino)pyridin-2yl moiety, the thioamides 16a-d (30\%-71\%) showed more potent ALK5 inhibition than the corresponding amides 14a-d at $10 \mu \mathrm{M}$. Among compounds containing a 4-methylthiazol-2-yl moiety, the thioamides $16 \mathbf{e}-\mathbf{h}(87 \%-98 \%)$ also showed similar ALK5 inhibition with the corresponding amides $\mathbf{1 4} \mathbf{e}-\mathbf{h}$ at $10 \mu \mathrm{M}$. We speculated that insertion of electron-donating groups at the 6-position of the pyridine moiety in $\mathbf{5}$ series compound would increase the capability of the nitrogen atom in that moiety as an H-bond acceptor, thus, potentiating its ALK5 inhibitory activity. But, instead, insertion of the 6-(dimethylamino)pyridin-2-yl moiety does not seem to fit ATP binding pocket of ALK5 compared to its structural counterparts bearing 6- 
146

147

148

149

150

\begin{tabular}{|c|c|c|c|c|}
\hline \multirow{2}{*}{ Compound } & \multirow{2}{*}{$\mathbf{R}$} & \multirow{2}{*}{$X$} & \multicolumn{2}{|c|}{ Residual activitya (\%) } \\
\hline & & & $\mathrm{p} 38 \alpha^{\mathrm{b}}$ & $\mathrm{ALK}^{\mathrm{c}}$ \\
\hline $14 a$ & $\mathrm{H}$ & $\mathrm{O}$ & 110 & 85 \\
\hline $14 b$ & $o-\mathrm{F}$ & $\mathrm{O}$ & 118 & 84 \\
\hline $14 c$ & $m-\mathrm{F}$ & $\mathrm{O}$ & 121 & 37 \\
\hline $14 d$ & $m-\mathrm{CN}$ & $\mathrm{O}$ & 121 & 95 \\
\hline $15 a$ & $\mathrm{H}$ & & 118 & 95 \\
\hline $15 b$ & $o-\mathrm{F}$ & & 117 & 87 \\
\hline $15 c$ & $m-\mathrm{F}$ & & 109 & 88 \\
\hline $15 d$ & $m-\mathrm{CN}$ & & 109 & 94 \\
\hline $16 \mathbf{a}$ & $\mathrm{H}$ & $S$ & 119 & 29 \\
\hline $16 b$ & $o-\mathrm{F}$ & $S$ & 125 & 70 \\
\hline $16 \mathrm{c}$ & $m-\mathrm{F}$ & $S$ & 165 & 29 \\
\hline $16 d$ & $m-\mathrm{CN}$ & $S$ & 119 & 54 \\
\hline $14 \mathrm{e}$ & $\mathrm{H}$ & $\mathrm{O}$ & 98 & 5 \\
\hline $14 f$ & $o-\mathrm{F}$ & $\mathrm{O}$ & 103 & 5 \\
\hline $14 \mathrm{~g}$ & $m-\mathrm{F}$ & $\mathrm{O}$ & 101 & 3 \\
\hline $14 \mathrm{~h}$ & $m-\mathrm{CN}$ & $\mathrm{O}$ & 108 & 3 \\
\hline $15 e$ & $\mathrm{H}$ & & 68 & 46 \\
\hline $15 f$ & $o-\mathrm{F}$ & & 54 & 73 \\
\hline $15 \mathrm{~g}$ & $m-\mathrm{F}$ & & 66 & 69 \\
\hline $15 \mathrm{~h}$ & $m-\mathrm{CN}$ & & 97 & 58 \\
\hline $16 e$ & $\mathrm{H}$ & $S$ & 102 & 5 \\
\hline $16 f$ & $o-\mathrm{F}$ & $S$ & 92 & 2 \\
\hline $16 \mathrm{~g}$ & $m-\mathrm{F}$ & $S$ & 109 & 2 \\
\hline $16 \mathrm{~h}$ & $m-\mathrm{CN}$ & $S$ & 105 & 13 \\
\hline \multicolumn{2}{|c|}{3 (LY-2157299) } & & 4 & 1 \\
\hline
\end{tabular}

methylpyrine. Fortunately, introduction of 4-methylthiazol-2-yl moiety effectively improved ALK5 inhibitory activity.

Table 1. Residual ALK5 and p38 $\alpha$ MAP kinase activities in the presence of 3-substituted-4(quinoxalin-6-yl) pyrazoles 14a-h, 15a-h, and 16a-h.

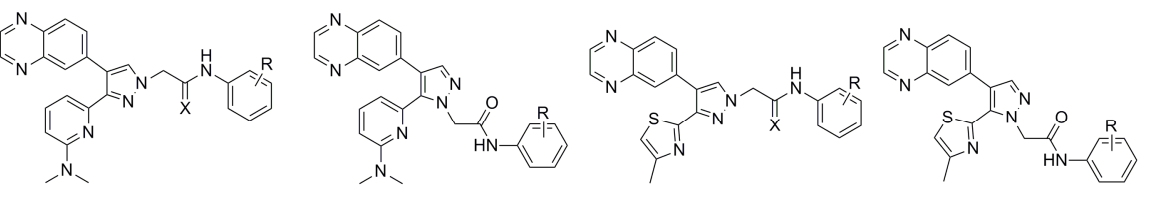

\footnotetext{
a Residual kinase activities were measured with each compound at $10 \mu \mathrm{M}$, in duplicate, in reactions containing p38 $\alpha$ and ALK5 protein kinases. ${ }^{\mathrm{b}}$ p38 $\alpha$ MAP kinase was expressed in E. coli as the untagged human recombinant protein. The enzyme was purified by Ni-NTH-agarose (Qiagen). A proprietary radioisotopic protein kinase assay ( ${ }^{33}$ PanQinase ${ }^{\circledR}$ Activity Assay) was performed at ProQinase $\mathrm{GmbH}$ (Freiburg, Germany), using ATF2 as a substrate. ${ }^{c}$ ALK5 was expressed in Sf9 insect cells as the human recombinant GST-fusion protein using the vaculovirus expression system. A proprietary radioisotopic protein kinase assay ( ${ }^{33}$ PanQinase ${ }^{\circledR}$ Activity Assay) was performed at ProQinase $\mathrm{GmbH}$ (Freiburg, Germany) using casein as a substrate.
}

\section{3. p38a MAP kinase assay}

We selected p38 $\alpha$ MAP kinase to survey the selectivity profile of this series of compounds because its kinase domain is among the most homologous to that of ALK5 [29]. All target compounds except 15e-h $(3 \%-46 \%)$ did not inhibit p38 $\alpha$ MAP kinase, even at their maximum concentration of 10 $\mu \mathrm{M}$, was reported in Table1. 
Fig 2 intuitively illustrates the inhibitory activity of 3-substituted-4-(quinoxalin-6-yl)pyrazoles against ALK5 and p38 $\alpha$ MAP kinase. All compounds with a 4-methylthiazol-2yl moiety (14e-h, 15e$\mathbf{h}$, and 16e-h) showed more potent ALK5 inhibition than those with a 6-(dimethylamino)pyridin-2yl moiety (14a-d, 15a-d, and 16a-d).

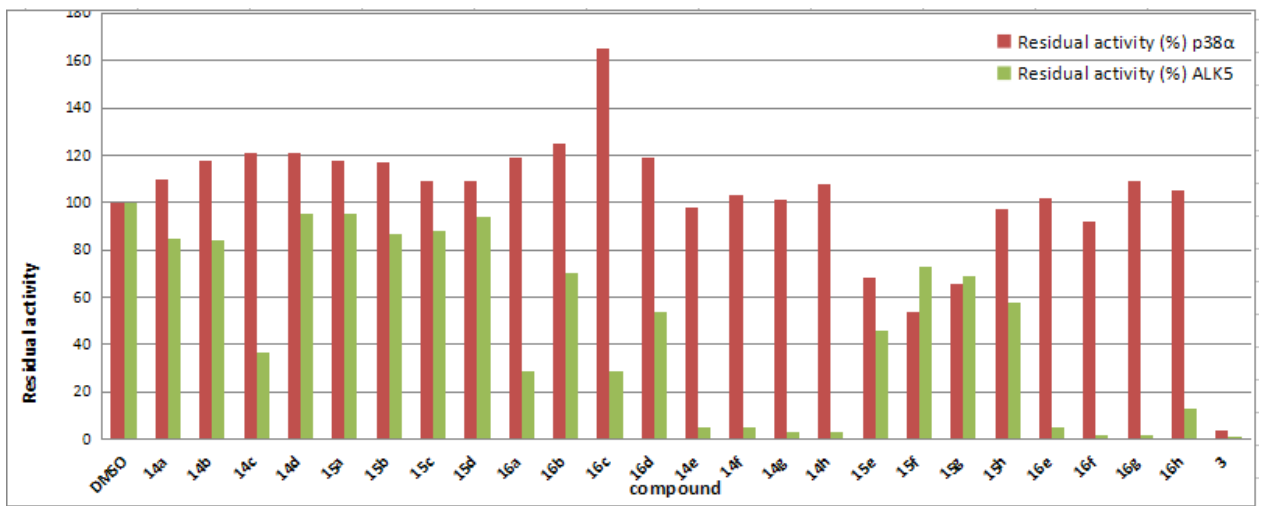

Figure 2. Residual activities of ALK5 and p38 $\alpha$ MAP kinase in the presence of 3-substituted-4(quinoxalin-6-yl)pyrazoles 14a-h, 15a-h, and 16a-h.

\subsection{ALK5 inhibitory activity in an enzymatic assay}

In previous studies, we found that the activity of thioamide compounds was superior to that of the corresponding amide ones [14]. To evaluate ALK5 inhibitory activity and selectivity of the compounds possessing 6-(dimethylamino)pyridin-2-yl or 4-methylthiazol-2-yl moieties as electron donating group, the thioamides $\mathbf{1 6 a}-\mathbf{h}$ were selected and their half maximal inhibitory concentration (IC50) values were measured. All compounds with a 4-methylthiazol-2-yl moiety (16e-h) showed potent ALK5 inhibition $\left(\mathrm{IC}_{50}=0.28-0.57 \mu \mathrm{M}\right)$, whereas those with a 6-(dimethylamino)pyridin-2-yl moiety (16a-d) showed no significant ALK5 inhibitory activity at up to $5.0 \mu \mathrm{M}$, was reported in Table2.

Table 2. Inhibitory activity of 3-substituted-4-(quinoxalin-6-yl) pyrazoles 16a-h, 22a, 22b, 22d, 23a, 23b, 23d, 24b, and 24d against ALK5 and p38 $\alpha$ MAP kinase.<smiles>[X]/C(=N\c1cccc(-c2cn(CC([X])Nc3cccc(N(C)C)n3)nc2-c2ccc3nccnc3c2)c1)Nc1ccccc1</smiles><smiles>[X]C(Cn1cc(-c2ccc3nccnc3c2)c(-c2nc(C)cs2)n1)Nc1ccccc1</smiles><smiles>[R]c1cccc(NC([X])Cn2cc(-c3ccc4nccnc4c3)c(-c3ccncn3)n2)c1</smiles>

\begin{tabular}{|c|c|c|c|c|c|}
\hline \multicolumn{3}{|c|}{$16 a-d$} & \multicolumn{3}{|c|}{$22 a, 22 b, 22 d, 24 b, 24 d$} \\
\hline \multirow[t]{2}{*}{ Compound } & \multirow[t]{2}{*}{$\mathbf{R}$} & \multirow[t]{2}{*}{$X$} & \multicolumn{2}{|c|}{$\mathrm{IC}_{50}(\mu \mathrm{M})$} & \multirow{2}{*}{$\begin{array}{c}\text { Selectivity } \\
\text { indexc }\end{array}$} \\
\hline & & & p38 $\alpha^{\mathrm{a}}$ & ALK5 $^{b}$ & \\
\hline $16 a$ & $\mathrm{H}$ & $S$ & $>10$ & 5.75 & $>2$ \\
\hline $16 b$ & $o-\mathrm{F}$ & $S$ & $>10$ & $>10$ & \\
\hline $16 c$ & $m-\mathrm{F}$ & $S$ & $>10$ & 5.00 & $>2$ \\
\hline $16 d$ & $m-\mathrm{CN}$ & $S$ & $>10$ & $>10$ & \\
\hline $16 e$ & $\mathrm{H}$ & $S$ & $>10$ & 0.57 & $>17$ \\
\hline $16 f$ & $o-\mathrm{F}$ & $S$ & $>10$ & 0.28 & $>35$ \\
\hline $16 \mathrm{~g}$ & $m-\mathrm{F}$ & $S$ & $>10$ & 0.33 & $>30$ \\
\hline $16 h$ & $m-\mathrm{CN}$ & $S$ & $>10$ & 0.37 & $>27$ \\
\hline $22 a$ & $\mathrm{H}$ & $\mathrm{O}$ & $>10$ & 5.03 & $>2$ \\
\hline $22 b$ & $o-\mathrm{F}$ & $\mathrm{O}$ & $>10$ & 3.66 & $>3$ \\
\hline $22 d$ & $m-\mathrm{CN}$ & $\mathrm{O}$ & $>10$ & 4.12 & $>2$ \\
\hline $23 a$ & $\mathrm{H}$ & $\mathrm{O}$ & $>10$ & $>10$ & \\
\hline
\end{tabular}


183

\subsection{Docking study of $16 b$ and $16 f$ in the ALK5 active site}

To rationalize the SAR shown in Tables 1 and 2, we examined the binding modes of two representative ligands (16b and $\mathbf{1 6 f}$ ) using the semi-flexible molecular docking program DS CDOCKER [30]. Docking analyses were performed using the recently reported X-ray structure of ALK5 complexed to a pyrazole ALK5 inhibitor (PDB: 1RWB)[13], as shown in Figure 3.

A
$>10$

$>10$

$>10$

2.26

0.12
$>4$

4

a p38 $\alpha$ MAP kinase was expressed in E. coli as untagged human recombinant protein. The enzyme was purified by Ni-NTH-agarose (Qiagen). A proprietary radioisotopic protein kinase assay (33PanQinase ${ }^{\circledR}$ Activity Assay) was performed at ProQinase GmbH (Freiburg, Germany) using ATF2 as a substrate. ${ }^{\mathrm{b}}$ ALK5 was expressed in Sf9 insect cells as a human recombinant GST-fusion protein using the vaculovirus expression system. A proprietary radioisotopic protein kinase assay (33PanQinase ${ }^{\circledR}$ Activity Assay) was performed at ProQinase GmbH (Freiburg, Germany), using casein as a substrate. ${ }^{\mathrm{c}} \mathrm{IC}_{50}$ of $\mathrm{p} 38 \alpha / \mathrm{IC}_{50}$ of ALK5.

To evaluate ALK5 inhibitory activity and selectivity of the compounds possessing pyrimidin-4yl moiety as multiple binding site, the amides $\mathbf{2 2} \mathbf{a}, \mathbf{2 2} \mathbf{b}, \mathbf{2 2} \mathbf{d}$ and thioamides $\mathbf{2 4 b}$ and $\mathbf{2 4 \mathbf { d }}$ were also selected and evaluated. However, all compounds with a pyrimidin-4-yl moiety (22a, 22b, 22d, 24b, 24d) also showed no significant ALK5 inhibition activity at up to $2.26 \mu \mathrm{M}$, was reported in Table2.

Compound 16f showed the most potent ALK5 inhibitory activity with an IC 50 value of $0.28 \mu \mathrm{M}$ in these three series of compounds. It was slightly less potent than compounds $3(0.12 \mu \mathrm{M})$. Furthermore, all thioamides $\mathbf{1 6} \mathbf{a}-\mathbf{h}, \mathbf{2 4 b}$ and $\mathbf{2 4 d}$ failed to inhibit p38 $\alpha$ MAP kinase up to $10.0 \mu \mathrm{M}$. Compound 16f was the most selective in these three series, showing a selectivity index of $>35$, higher than that of positive control compound $\mathbf{3}(4)$. In this series of compounds $(\mathbf{1 6} \mathbf{e}-\mathbf{h})$, the activity of compounds with substituents is superior to that of unsubstituted one. Notably, 2-fluorine substituted compound 16f, which is 2 -fold more potent than unsubstituted compound $16 \mathbf{e}\left(\mathrm{IC}_{50}=0.57 \mu \mathrm{M}\right)$.

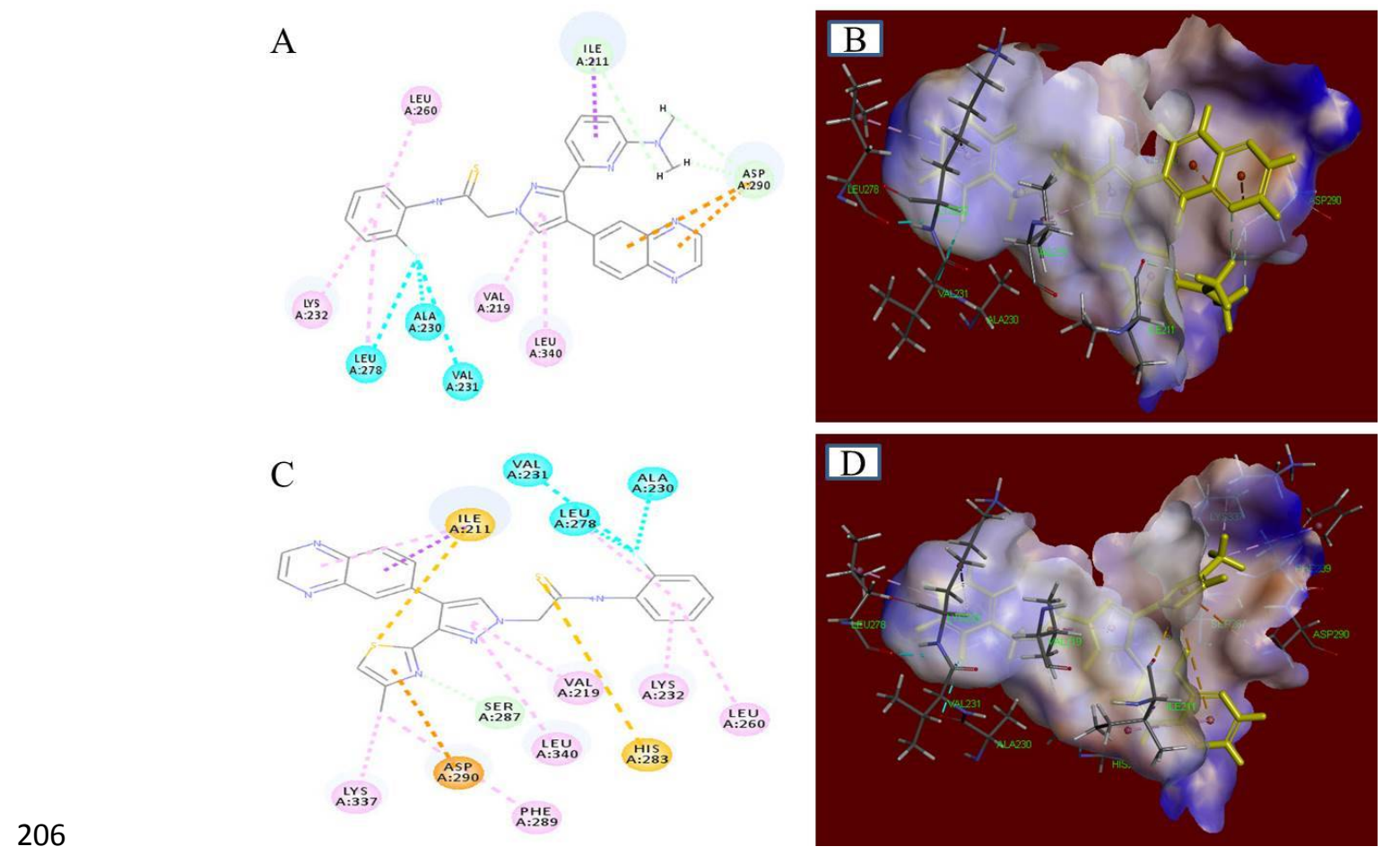


Figure 3. Docking pose of compounds $\mathbf{1 6 b}$ and $\mathbf{1 6 f}$ in the active site of ALK5 (PDB: 1RWB). (A) 2D binding model of $\mathbf{1 6 b}$. (B) Proposed pose of $\mathbf{1 6 b}$ in the binding pocket of ALK5. (C) 2D binding model of 16f. (D). Proposed pose of $\mathbf{1 6 f}$ in the binding pocket of ALK5. The ligands are shown in yellow.

The sulfur atom of the thioamide in $\mathbf{1 6 f}$ contacted the hinge of ALK5, forming hydrogen bonds with the imidazole ring of His283, a residue previously reported to be important for inhibitory activity (Fig 3C) [14]. The phenyl ring of $\mathbf{1 6 f}$ interacted with Lys232 via Pi-alkyl bond. The central pyrazole ring of $\mathbf{1 6 f}$ formed Pi-alkyl bond with the side chains of Leu340 and Val219. The thiazole N atom of $\mathbf{1 6 f}$ formed carbon-hydrogen bond with the backbone of Ser287 and the methyl group of $\mathbf{1 6 f}$ formed alkyl bond with the backbone of Lys337 and Pi-alkyl bond with the backbone of Phe289. Not only the calculated binding energy scores (CDOCKER_INTERATION_ENERGY) of these two compounds indicated that $16 \mathrm{f}(-56.18 \mathrm{kcal} / \mathrm{mol})$ formed more stable complexes with ALK5 than did 16b $(-54.81 \mathrm{kcal} / \mathrm{mol})$, but also compound 16f (Lys232, His283, Ser287, Leu340 and Lys337) showed more bonding with previously reported key amino acids than did compound 16b (Lys232 and Leu340) (Fig 3A) (Jin et al. 2014; Jin et al. 2011a; Gellibert et al. 2009). In particular, compound 16b did not form bond with the most important amino acid, His283. The 2-fluorophenyl ring of $\mathbf{1 6} \mathbf{b}$ and $\mathbf{1 6 f}$ was stretched to the backside hydrophobic pocket consisting of Lys232, Leu260, Leu278, Val231 and Ala230. Furthermore, compound $\mathbf{1 6 f}$ seemed to be more favorably accommodated in the binding pocket of ALK5 than compound 16b (Fig 3B and 3D). Our docking results indicated that the most active compound, 16f, showed the more favorable intermolecular interactions in the ALK5 active site than compound $\mathbf{1 6 b}$. This supported the conclusion that the substitution group size of the pyridine moiety and selection of a heterocycle in compound 5 may have been important for improving ALK5 inhibition.

\subsection{ADMET Analysis}

ADMET pharmacokinetics is very important method in drug design and drug screening, which is responsible for drug failure [32,33]. The ADMET properties of the drug molecules are greatly influenced by the optimum value of the intestinal absorption, water solubility, blood brain barrier (BBB) penetration, human cytochrome P450 2D6 (CYP2D6) inhibition, hepatotoxicity, and plasma protein binding (PPB) level. The ADMET parameters of these good targeted compounds 16e-h was measured using Discovery Studio software as a drug reference was reported in Table 3. 
Table 3. Prediction of ADMET properties of compounds 16e-h.

\begin{tabular}{ccccccc}
\hline Compd & Absorption $^{\mathrm{a}}$ & Solubility $^{\mathrm{b}}$ & BBB $^{\mathrm{c}}$ & CYP2D6 $^{\mathrm{d}}$ & Hepatotoxicity $^{\mathrm{e}}$ & PPB $^{\mathrm{f}}$ \\
\hline $\mathbf{1 6 e}$ & 0 & -5.72 & 1 & False & Ture & True \\
$\mathbf{1 6 f}$ & 0 & -5.998 & 1 & False & Ture & True \\
$\mathbf{1 6 g}$ & 0 & -5.997 & 1 & False & Ture & True \\
$\mathbf{1 6 h}$ & 0 & -5.541 & 4 & False & Ture & True \\
$\mathbf{3}$ & 0 & -5.415 & 2 & False & Ture & True \\
\hline
\end{tabular}

a Predicted human intestinal absorption level (acceptable level: 0 is good, 1 is moderate and 2 is low).

b Predicted aqueous solubility at room temperature (acceptable range: $-6.0<\log (\mathrm{SW})<-4.1$ is low and $4.1<\log (\mathrm{SW})<-2.0$ is good).

c Predicted blood brain barrier (BBB) penetration level (acceptable range: 0 is very high, 1 is high, 2 is medium, 3 is low, 4 is undefined)

d Predicted human cytochrome P450 2D6 (CYP2D6) inhibitory ability (acceptable level: False is good)

e Predicted hepatotoxicity possibility (acceptable level: False is good and True is bad)

${ }^{\mathrm{f}}$ Predicted plasma protein binding (PPB) possibility (acceptable level: True is good).

The preferred and most widely used route of drug is the oral route, and the mechanism of absorption from the gastrointestinal tract is passive diffusion through the intestinal epithelial cells. Hence, the absorption and solubility of the drug are two major factors for oral administration. All of the 3-substituted-4-(quinoxalin-6-yl) pyrazoles $\mathbf{1 6} \mathbf{e}-\mathbf{h}$ showed good intestinal absorption. All compounds showed low or very low aqueous solubility at room temperature. But the structure of these compounds contain thiazole and quinoxaline moiety, so it is easy to make salt in stomach acid and dissolve in water. The BBB is an important organizational structure to maintain the stability of the central nervous system, which maintains the relative stability of the environment in the nervous system by restricting the entry of compounds into the central nervous system, and protects nerve cells from being invaded by harmful substances. All compounds, except compound 16h, showed BBB penetration in permissible level (1). These compounds are suitable for the treatment of systemic diseases. Compound 16h showed low BBB permeability and is suitable for non-brain diseases, which is characterized by cyano group at 3-position on the phenyl ring. In addition, the PPB binding ability of all compounds was good. CYP2D6 is an important drug metabolism enzyme in the family of cytochrome P450, and its catalysis is widely used. Over the years, the genes encoding CYP2D6 enzyme have been closely related to the genetic polymorphism, drug metabolism, production of adverse drug reactions and activation of carcinogens. Also, all compounds did not inhibit CYP2D6, so they will be shown no or low side effects such as drug-drug interaction and wide metabolism. But all compounds showed a certain hepatotoxicity as clinical candidate, 3 (LY-2157299). All of the parameters were within the acceptable range defined for human use and these good targeted compounds may exhibit significant pharmacokinetic and drug-likeliness properties.

\section{Experimental}

\subsection{Chemistry}

All solvents and chemicals were commercially available without further purification. In general, all reactions were performed under normal atmosphere and at room temperature unless otherwise noted. Melting points were measured in open glass capillaries tube in an electrical melting point and are uncorrected. Spots were detected by viewing under UV lamps $(254 \mathrm{~nm}) .{ }^{1} \mathrm{H}$ and ${ }^{13} \mathrm{C}$ NMR spectra were recorded on Bruker NMR spectrometers at $300 \mathrm{MHz}$ and $500 \mathrm{MHz}$, respectively, tetramethylsilane (TMS) was used as internal standard. High resolution mass spectra electrospray ionization (HRMS-ESI) was obtained on a Thermo Scientific LTQ Orbitrap XL spectrometer. The purity of the tested compounds was determined using an Agilent 1260 series HPLC system using a $\mathrm{C}_{18}$ column (packing ODS HG $5 \mu \mathrm{M}, 4.6 \times 250 \mathrm{~mm}$ ), and that for all the compounds was found to be $>95 \%$. 
3.1.1. General procedure for the preparation of diphenyl ((6-(dimethylamino)pyridin-2yl)(phenylamino)methyl)phosphonate (10a) , diphenyl ((4-methylthiazol-2yl)(phenylamino)methyl)phosphonate (10b) and diphenyl ((phenylamino)(pyrimidin-4yl)methyl)phosphonate (18)

To a stirred solution of $\mathbf{8}, \mathbf{9}$ or $\mathbf{1 7}(12.90 \mathrm{mmol})$ in $i-\mathrm{PrOH}(40 \mathrm{~mL})$, aniline $(15.48 \mathrm{mmol})$ and diphenyl phosphite $(20.64 \mathrm{mmol})$ were added. The mixture was stirred at room temperature for $4 \mathrm{~h}$. The reaction mixture evaporated to dryness under reduced pressure. The residue was purified by silica gel column chromatography (Petroleum ether/Ethyl acetate, 6:1) to give the titled compound $10 \mathrm{a}, 10 \mathrm{~b}$ or 18 as a white solid.

Diphenyl ((6-(dimethylamino)pyridin-2-yl)(phenylamino)methyl)phosphonate (10a): Yield $90 \%$; ${ }^{1} \mathrm{H}$ NMR $\left(300 \mathrm{MHz}, \mathrm{CDCl}_{3}\right) \delta 7.42(\mathrm{t}, J=9.0 \mathrm{~Hz}, 1 \mathrm{H}), 7.36-7.21(\mathrm{~m}, 6 \mathrm{H}), 7.18-7.08(\mathrm{~m}, 6 \mathrm{H}), 6.86-6.77(\mathrm{~m}$, $4 \mathrm{H}), 6.42(\mathrm{dd}, J=9.0,3.0 \mathrm{~Hz}, 1 \mathrm{H}), 5.56(\mathrm{br} \mathrm{s}, 1 \mathrm{H}), 5.27(\mathrm{~d}, J=18.0 \mathrm{~Hz}, 1 \mathrm{H}), 3.09(\mathrm{~s}, 6 \mathrm{H})$.

Diphenyl ((4-methylthiazol-2-yl)(phenylamino)methyl)phosphonate (10b): Yield 70\%; ${ }^{1} \mathrm{H}$ NMR (300 $\left.\mathrm{MHz}, \mathrm{CDCl}_{3}\right) \delta 7.36-7.14(\mathrm{~m}, 10 \mathrm{H}), 7.04(\mathrm{~d}, J=9.0 \mathrm{~Hz}, 2 \mathrm{H}), 6.85-6.80(\mathrm{~m}, 2 \mathrm{H}), 6.73(\mathrm{~d}, J=9.0 \mathrm{~Hz}, 1 \mathrm{H})$, $6.21(\mathrm{br} \mathrm{s}, 1 \mathrm{H}), 5.58(\mathrm{~d}, J=24.0 \mathrm{~Hz}, 1 \mathrm{H}), 2.41(\mathrm{~s}, 3 \mathrm{H})$.

Diphenyl ((phenylamino)(pyrimidin-4-yl)methyl)phosphonate (18): Yield 31\%; ${ }^{1} \mathrm{H}$ NMR $(300 \mathrm{MHz}$, $\left.\mathrm{CDCl}_{3}\right) \delta 9.23(\mathrm{~s}, 1 \mathrm{H}), 8.68(\mathrm{~d}, J=3.0 \mathrm{~Hz}, 1 \mathrm{H}), 7.62(\mathrm{~s}, 1 \mathrm{H}), 7.27-7.01(\mathrm{~m}, 13 \mathrm{H}), 6.79(\mathrm{t}, J=9.0 \mathrm{~Hz}, 1 \mathrm{H})$, $6.70(\mathrm{~d}, J=9.0 \mathrm{~Hz}, 1 \mathrm{H}), 6.09(\mathrm{br} \mathrm{s}, 1 \mathrm{H}), 5.30(\mathrm{~d}, J=24.0 \mathrm{~Hz}, 1 \mathrm{H})$.

3.1.2. General procedure for the preparation of 1-(6-(dimethylamino)pyridin-2-yl)-2-(quinoxalin-6yl)ethanone (11a) 1-(4-methylthiazol-2-yl)-2-(quinoxalin-6-yl)ethanone (11b) and 1-(pyrimidin-4yl)-2-(quinoxalin-6-yl)ethan-1-one (19)

To a stirred solution of $\mathbf{1 0 a}, \mathbf{1 0 b}$ or $\mathbf{1 8}(10.9 \mathrm{mmol})$ in a mixture of THF $(23.2 \mathrm{~mL})$ and $i-\operatorname{PrOH}(5.8$ $\mathrm{mL}), \mathrm{Cs}_{2} \mathrm{CO}_{3}(1.41 \mathrm{mmol})$ and quinoxaline-6-carbaldehyde $(10.9 \mathrm{mmol})$ were added. The mixture was stirred at room temperature for $16 \mathrm{~h}$, and to it, $1 \mathrm{~N} \mathrm{HCl}(43.4 \mathrm{~mL})$ was added dropwise over a period of $5 \mathrm{~min}$. The reaction mixture was diluted with tert-butyl methyl ether (MTBE) (17.4 mL). The aqueous layer was separated, and the organic layer was extracted with $1 \mathrm{~N} \mathrm{HCl}(3 \times 50 \mathrm{~mL})$. The combined aqueous layer was neutralized with saturated $\mathrm{NaHCO}_{3}$ solution $(\mathrm{pH} 7-8)$ and extracted with EtOAc $(3 \times 100 \mathrm{~mL})$. The EtOAc solution was dried over anhydrous $\mathrm{Na}_{2} \mathrm{SO}_{4}$, filtered, and evaporated to dryness under reduced pressure. The residue was purified by silica gel column chromatography (Petroleum ether/Ethyl acetate, 4:1) to give the titled compound 11a, 11b or 19 as a yellow solid.

1-(6-(Dimethylamino)pyridin-2-yl)-2-(quinoxalin-6-yl)ethanone (11a): Yield 71\%; ${ }^{1} \mathrm{H}$ NMR (300 MHz, DMSO- $\left.d_{6}\right) \delta 8.92(\mathrm{~d}, J=3.0 \mathrm{~Hz}, 2 \mathrm{H}), 8.06(\mathrm{~d}, J=9.0 \mathrm{~Hz}, 1 \mathrm{H}), 8.01(\mathrm{~s}, 1 \mathrm{H}), 7.80(\mathrm{~d}, J=9.0 \mathrm{~Hz}, 1 \mathrm{H}), 7.69$ $(\mathrm{t}, J=7.5 \mathrm{~Hz}, 1 \mathrm{H}), 7.22(\mathrm{~d}, J=9.0 \mathrm{~Hz}, 1 \mathrm{H}), 6.94(\mathrm{~d}, J=6.0 \mathrm{~Hz}, 1 \mathrm{H}), 4.76(\mathrm{~s}, 2 \mathrm{H}), 3.15(\mathrm{~s}, 6 \mathrm{H})$.

1-(4-Methylthiazol-2-yl)-2-(quinoxalin-6-yl)ethanone (11b): Yield 52\%; ${ }^{1} \mathrm{H}$ NMR (300 MHz, DMSO$\left.d_{6}\right) \delta 8.95(\mathrm{br} \mathrm{s}, 2 \mathrm{H}), 8.08(\mathrm{~d}, J=9.0 \mathrm{~Hz}, 2 \mathrm{H}), 7.88(\mathrm{~s}, 1 \mathrm{H}), 7.82(\mathrm{~d}, J=9.0 \mathrm{~Hz}, 1 \mathrm{H}), 4.81(\mathrm{~s}, 2 \mathrm{H}), 2.54(\mathrm{~s}$, $3 \mathrm{H})$.

1-(Pyrimidin-4-yl)-2-(quinoxalin-6-yl)ethan-1-one (19): Yield 62\%; ${ }^{1} \mathrm{H}$ NMR (300 MHz, CDCl $) \delta 9.45$ $(\mathrm{s}, 1 \mathrm{H}), 9.01(\mathrm{~d}, J=6.0 \mathrm{~Hz}, 1 \mathrm{H}), 8.83(\mathrm{~s}, 2 \mathrm{H}), 8.11-8.06(\mathrm{~m}, 2 \mathrm{H}), 7.94(\mathrm{~d}, J=3.0 \mathrm{~Hz}, 1 \mathrm{H}), 7.75(\mathrm{~d}, J=9.0$ $\mathrm{Hz}, 1 \mathrm{H}), 4.79(\mathrm{~s}, 2 \mathrm{H})$.

3.1.3. General procedure for the preparation of $N, N$-dimethyl-6-(4-(quinoxalin-6-yl)-1H-pyrazol-3yl)pyridin-2-amine (12a) 4-methyl-2-(4-(quinoxalin-6-yl)-1H-pyrazol-3-yl)thiazole (12b) and 6-(3(pyrimidin-4-yl)-1H-pyrazol-4-yl)quinoxaline (20) 
To a stirred solution of $\mathbf{1 1 a}, \mathbf{1 1 b}$ or $19(1.71 \mathrm{mmol})$ in anhydrous DMF (4.5 mL), N,Ndimethylformamide dimethyl acetal $(5.12 \mathrm{mmol})$ were added. The mixture was heated at $80^{\circ} \mathrm{C}$ for 4 h. After cooled to room temperature, the reaction mixture was evaporated to dryness under reduced pressure. The residue was dissolved in $\mathrm{EtOH}(6.43 \mathrm{~mL})$, and to it, hydrazine monohydrate (35.36 mmol) was added. The mixture was heated at reflux temperature for $4 \mathrm{~h}$, then cooled to room temperature, and evaporated to dryness under reduced pressure. The residue was diluted with $\mathrm{CH}_{2} \mathrm{Cl}_{2}(60 \mathrm{~mL})$ and washed with water $(20 \mathrm{~mL})$ and brine $(20 \mathrm{~mL})$. The $\mathrm{CH}_{2} \mathrm{Cl}_{2}$ solution was dried over anhydrous $\mathrm{Na}_{2} \mathrm{SO}_{4}$, filtered, and evaporated to dryness under reduced pressure. The residue was purified by silica gel column chromatography (Petroleum ether/Ethyl acetate, 1:1) to give the titled compound $\mathbf{1 2 a}, \mathbf{1 2 b}$ or $\mathbf{2 0}$ as a yellow solid.

N,N-Dimethyl-6-(4-(quinoxalin-6-yl)-1H-pyrazol-3-yl)pyridin-2-amine (12a): Yield 68\%; ${ }^{1} \mathrm{H}$ NMR $\left(300 \mathrm{MHz} \mathrm{CDCl}_{3}\right) \delta 8.84(\mathrm{~d}, J=6.0 \mathrm{~Hz}, 2 \mathrm{H}), 8.21(\mathrm{~d}, J=3.0 \mathrm{~Hz}, 1 \mathrm{H}), 8.10(\mathrm{~d}, J=9.0 \mathrm{~Hz}, 1 \mathrm{H}), 7.88(\mathrm{dd}, J$ $=9.0,3.0 \mathrm{~Hz}, 1 \mathrm{H}), 7.77(\mathrm{~s}, 1 \mathrm{H}), 7.32(\mathrm{t}, J=9.0 \mathrm{~Hz}, 1 \mathrm{H}), 6.68(\mathrm{~d}, J=9.0 \mathrm{~Hz}, 1 \mathrm{H}), 6.48(\mathrm{~d}, J=9.0 \mathrm{~Hz}, 1 \mathrm{H})$, $3.10(\mathrm{~s}, 6 \mathrm{H})$.

4-Methyl-2-(4-(quinoxalin-6-yl)-1H-pyrazol-3-yl)thiazole (12b): Yield 71\%; ${ }^{1} \mathrm{H}$ NMR (300 MHz, $\left.\mathrm{CDCl}_{3}\right) \delta 8.87(\mathrm{~d}, J=3.0 \mathrm{~Hz}, 2 \mathrm{H}), 8.29(\mathrm{~d}, J=3.0 \mathrm{~Hz}, 1 \mathrm{H}), 8.15(\mathrm{~d}, J=9.0 \mathrm{~Hz}, 1 \mathrm{H}), 7.95(\mathrm{dd}, J=9.0,3.0$ $\mathrm{Hz}, 1 \mathrm{H}), 7.87$ (s, 1H), $6.87(\mathrm{~s}, 1 \mathrm{H}), 2.49$ (s, 3H).

6-(3-(Pyrimidin-4-yl)-1H-pyrazol-4-yl)quinoxaline (20): Yield 58\%; ${ }^{1} \mathrm{H}$ NMR (300 MHz, DMSO-d6) $\delta$ 13.72 (s, 1H), 9.02 (s, 1H), 8.93 (br s, 2H), 8.85 (br s, 1H), 8.36 (br s, 1H), 8.14 (s, 1H), 8.03 (br s, $1 \mathrm{H})$, $7.91(\mathrm{~d}, J=9.0 \mathrm{~Hz}, 2 \mathrm{H})$.

3.1.4. General procedure for the preparation of 2-(3-(6-(dimethylamino)pyridin-2-yl)-, 2-(3-(4methylthiazol-2-yl)- or 2-(3-(pyrimidin-4-yl)-4-(quinoxalin-6-yl)-1H-pyrazol-1-yl)acetamide (14a-h, 22a, 22b, 22d) and 2-(5-(6-(dimethylamino)pyridin-2-yl)-, 2-(5-(4-methylthiazol-2-yl)- or 2-(5(pyrimidin-4-yl)-4-(quinoxalin-6-yl)-1H-pyrazol-1-yl)-N-phenylacetamide (15a-k, 23a, 23b, 23d)

To a solution of pyrazole 12a, 12b or $20(0.63 \mathrm{mmol})$ in anhydrous DMF $(8.3 \mathrm{~mL})$, a catalytic amount of sodium iodide, $\mathrm{NaH}(0.75 \mathrm{mmol})$, and 2-chloro- $\mathrm{N}$-phenylacetamide 13a, 13b, 13c, 13d, 21a, $\mathbf{2 1 b}$ or $\mathbf{2 1 d}(0.79 \mathrm{mmol})$ were added. The mixture was stirred at room temperature for $2 \mathrm{~h}$ and then evaporated to dryness under reduced pressure. The residue was purified by silica gel column chromatography (dichloromethane/methanol, 50:1) to give the two positional isomers 14a-k, 22a, 22b, 22d and 15a-k, 23a, 23b, 23d as white solids.

2-(3-(6-(Dimethylamino)pyridin-2-yl)-4-(quinoxalin-6-yl)-1H-pyrazol-1-yl)-N-phenylacetamide (14a) : Yield 54\%; HPLC purity: 98.68\% (acetonitrile: 40\%); mp 212.5-214.0 $\left.{ }^{\circ} \mathrm{C} ;{ }^{1} \mathrm{H} \mathrm{NMR} \mathrm{(300} \mathrm{MHz}_{2} \mathrm{CDCl}_{3}\right)$ $\delta 8.87$ (br s, 1H, NH), $8.84(\mathrm{~d}, J=6.0 \mathrm{~Hz}, 2 \mathrm{H}), 8.18(\mathrm{~s}, 1 \mathrm{H}), 8.04(\mathrm{~d}, J=9.0 \mathrm{~Hz}, 1 \mathrm{H}), 7.84(\mathrm{dd}, J=9.0,3.0$ $\mathrm{Hz}, 1 \mathrm{H}), 7.80(\mathrm{~s}, 1 \mathrm{H}), 7.58-7.52(\mathrm{~m}, 3 \mathrm{H}), 7.34(\mathrm{t}, J=9.0 \mathrm{~Hz}, 2 \mathrm{H}), 7.15(\mathrm{~d}, J=9.0 \mathrm{~Hz}, 2 \mathrm{H}), 6.49(\mathrm{~d}, J=6.0$ $\mathrm{Hz}, 1 \mathrm{H}), 5.06$ (s, 2H), 2.72 (s, 6H); ${ }^{13} \mathrm{C} \mathrm{NMR}\left(75 \mathrm{MHz}, \mathrm{CDCl}_{3}\right) \delta 164.60,158.64,151.02,149.38,145.10$, 144.50, 142.95, 142.02, 137.87, 137.07, 135.58, 132.76, 132.50, 129.02 (2C), 128.50, 128.14, 124.86, 121.69, 120.19 (2C), 109.86, 105.36, 55.91, 37.58 (2C); HRMS-ESI (m/z): [M+H] $]^{+}$calcd for $\mathrm{C}_{26} \mathrm{H}_{24} \mathrm{~N}_{7} \mathrm{O} 450.20368$, found 450.20370 .

2-(3-(6-(Dimethylamino)pyridin-2-yl)-4-(quinoxalin-6-yl)-1H-pyrazol-1-yl)-N-(2fluorophenyl)acetamide (14b): Yield 40\%; mp 190.5-193.0 ${ }^{\circ}$; HPLC purity: 99.39\% (acetonitrile: 40\%); ${ }^{1} \mathrm{H}$ NMR $\left(300 \mathrm{MHz}, \mathrm{CDCl}_{3}\right) \delta 9.30(\mathrm{~s}, 1 \mathrm{H}), 8.81(\mathrm{~d}, J=6.0 \mathrm{~Hz}, 2 \mathrm{H}), 8.31(\mathrm{t}, J=7.5 \mathrm{~Hz}, 1 \mathrm{H}), 8.16(\mathrm{~d}$, $J=3.0 \mathrm{~Hz}, 1 \mathrm{H}), 8.01(\mathrm{~d}, J=9.0 \mathrm{~Hz}, 1 \mathrm{H}), 7.83(\mathrm{dd}, J=9.0,3.0 \mathrm{~Hz}, 1 \mathrm{H}), 7.76(\mathrm{~s}, 1 \mathrm{H}), 7.54(\mathrm{t}, J=7.5 \mathrm{~Hz}, 1 \mathrm{H})$, $7.25(\mathrm{~d}, J=6.0 \mathrm{~Hz}, 1 \mathrm{H}), 7.17-7.06(\mathrm{~m}, 3 \mathrm{H}), 6.45(\mathrm{~d}, J=9.0 \mathrm{~Hz}, 1 \mathrm{H}), 5.06(\mathrm{~s}, 2 \mathrm{H}), 2.64(\mathrm{~s}, 6 \mathrm{H}) ;{ }^{13} \mathrm{C} \mathrm{NMR}$ $\left(125 \mathrm{MHz}, \mathrm{DMSO}-d_{6}\right) \delta 166.30,158.69,153.95(\mathrm{~d}, J=243.75 . \mathrm{Hz}), 150.70,149.00,146.16,145.38,142.74$, $141.50,138.21,136.43,133.76,132.70,128.58,127.50,126.10(\mathrm{~d}, J=16.25 \mathrm{~Hz}), 126.09,124.97(\mathrm{~d}, J=3.75$ $\mathrm{Hz}), 124.24,120.25,116.07(\mathrm{~d}, J=18.75 \mathrm{~Hz}), 110.08,105.21 .55 .01,30.48(2 \mathrm{C}) ; \mathrm{HRMS}-\mathrm{ESI}(\mathrm{m} / \mathrm{z}):[\mathrm{M}+\mathrm{H}]^{+}$ calcd for $\mathrm{C}_{26} \mathrm{H}_{23} \mathrm{FN} 7 \mathrm{O} 468.19426$, found 468.19427 . 
2-(3-(6-(Dimethylamino)pyridin-2-yl)-4-(quinoxalin-6-yl)-1H-pyrazol-1-yl)-N-(3-

fluorophenyl)acetamide (14c): Yield 50\%; mp 176.5-178.5 ${ }^{\circ} \mathrm{C}$; HPLC purity: 98.18\% (acetonitrile: $40 \%) ;{ }^{1} \mathrm{H}$ NMR $\left(300 \mathrm{MHz}, \mathrm{CDCl}_{3}\right) \delta 9.16(\mathrm{~s}, 1 \mathrm{H}), 8.87-8.82(\mathrm{~m}, 2 \mathrm{H}), 8.15(\mathrm{~s}, 1 \mathrm{H}), 8.03(\mathrm{~d}, J=9.0 \mathrm{~Hz}, 1 \mathrm{H})$, $7.83-7.78(\mathrm{~m}, 2 \mathrm{H}), 7.56-7.48(\mathrm{~m}, 2 \mathrm{H}), 7.32-7.22(\mathrm{~m}, 2 \mathrm{H}), 7.16(\mathrm{~d}, J=9.0 \mathrm{~Hz}, 1 \mathrm{H}), 7.11(\mathrm{~d}, J=9.0 \mathrm{~Hz}, 1 \mathrm{H})$, $6.83(\mathrm{t}, J=8.0 \mathrm{~Hz}, 1 \mathrm{H}), 6.48(\mathrm{~d}, J=9.0 \mathrm{~Hz}, 1 \mathrm{H}), 5.03(\mathrm{~s}, 2 \mathrm{H}), 2.71(\mathrm{~s}, 6 \mathrm{H}) ;{ }^{13} \mathrm{C} \mathrm{NMR}\left(75 \mathrm{MHz}, \mathrm{CDCl}_{3}\right) \delta$ 164.71, 161.23, $154.77(\mathrm{~d}, J=252.0 \mathrm{~Hz}), 153.97,153.51,145.10,144.52,142.90,141.98,138.28,135.79$, 135.36, $132.52(\mathrm{~d}, J=7.5 \mathrm{~Hz}), 130.03(\mathrm{~d}, J=9.0 \mathrm{~Hz}), 128.62,128.04,121.69,115.44,111.41(\mathrm{~d}, J=20.7 \mathrm{~Hz})$, 110.07, 107.71, $107.40(\mathrm{~d}, J=6.75 \mathrm{~Hz}), 105.83,55.82,30.93(2 \mathrm{C})$; HRMS-ESI $(\mathrm{m} / \mathrm{z})$ : $[\mathrm{M}+\mathrm{H}]^{+}$calcd for $\mathrm{C}_{26} \mathrm{H}_{23} \mathrm{FN}_{7} \mathrm{O} 468.19426$, found 468.19431.

N-(3-Cyanophenyl)-2-(3-(6-(dimethylamino)pyridin-2-yl)-4-(quinoxalin-6-yl)-1H-pyrazol-1yl)acetamide (14d): Yield 45\%; mp 218.5-221.5 ${ }^{\circ} \mathrm{C}$; HPLC purity: 99.52\% (acetonitrile: $\left.40 \%\right) ;{ }^{1} \mathrm{H}$ NMR $\left(300 \mathrm{MHz} \mathrm{CDCl}_{3}\right) \delta 9.39(\mathrm{~s}, 1 \mathrm{H}), 8.83(\mathrm{~d}, J=3.0 \mathrm{~Hz}, 2 \mathrm{H}), 8.14(\mathrm{~d}, J=3.0 \mathrm{~Hz}, 1 \mathrm{H}), 8.02(\mathrm{~d}, J=9.0 \mathrm{~Hz}$, $1 \mathrm{H}), 7.94(\mathrm{~s}, 1 \mathrm{H}), 7.81-7.78(\mathrm{~m}, 2 \mathrm{H}), 7.71-7.68(\mathrm{~m}, 1 \mathrm{H}), 7.53(\mathrm{t}, J=9.0 \mathrm{~Hz}, 1 \mathrm{H}), 7.41(\mathrm{~d}, J=6.0 \mathrm{~Hz}, 2 \mathrm{H})$, $7.07(\mathrm{~d}, J=9.0 \mathrm{~Hz}, 1 \mathrm{H}), 6.49(\mathrm{~d}, J=9.0 \mathrm{~Hz}, 1 \mathrm{H}), 5.05(\mathrm{~s}, 2 \mathrm{H}), 2.73(\mathrm{~s}, 6 \mathrm{H}) ;{ }^{13} \mathrm{C}$ NMR $\left(75 \mathrm{MHz}, \mathrm{DMSO}-d_{6}\right)$ $\delta 166.48,158.67,150.65,149.04,146.17,145.38,142.72,141.49,139.80,138.21,136.41,133.77,132.69$, $130.92,128.59,127.79,127.50,124.32,122.42,120.30,119.07,112.20,110.08,105.21,55.28,37.61$ (2C); HRMS-ESI (m/z): [M+H] $]^{+}$calcd for $\mathrm{C}_{27} \mathrm{H}_{23} \mathrm{~N}_{8} \mathrm{O} 475.19893$, found 475.19891.

2-(3-(4-Methylthiazol-2-yl)-4-(quinoxalin-6-yl)-1H-pyrazol-1-yl)-N-phenylacetamide (14e) : Yield 65\%; mp 190.2-192.5॰C; HPLC purity: 99.29\% (acetonitrile: 45\%); ${ }^{\circ} \mathrm{H}$ NMR (300 MHz, CDCl $/ \mathrm{DMSO}^{\circ}$ d6) $\delta 9.28(\mathrm{~s}, 1 \mathrm{H}), 8.86$ (br s, 2H), $8.27(\mathrm{~s}, 1 \mathrm{H}), 8.10(\mathrm{~d}, J=9.0 \mathrm{~Hz}, 1 \mathrm{H}), 7.94(\mathrm{~d}, J=9.0 \mathrm{~Hz}, 1 \mathrm{H}), 7.88(\mathrm{~s}$, $1 \mathrm{H}), 7.58(\mathrm{~d}, J=9.0 \mathrm{~Hz}, 2 \mathrm{H}), 7.30(\mathrm{~d}, J=9.0 \mathrm{~Hz}, 2 \mathrm{H}), 7.10(\mathrm{t}, J=6.0 \mathrm{~Hz}, 1 \mathrm{H}), 6.89(\mathrm{~s}, 1 \mathrm{H}), 5.19(\mathrm{~s}, 2 \mathrm{H})$, $2.44(\mathrm{~s}, 3 \mathrm{H}) ;{ }^{13} \mathrm{C} \mathrm{NMR}\left(75 \mathrm{MHz}, \mathrm{CDCl}_{3}\right) \delta 164.16,159.08,153.48,145.30,144.90,144.50$ (2C), 142.95, 142.47, 137.05, 133.28, 132.86, 132.05, 129.06, 129.03 (2C), 124.92, 121.60, 120.14 (2C), 114.49, 55.99, 17.05; HRMS-ESI (m/z): [M+H] $]^{+}$calcd for $\mathrm{C}_{23} \mathrm{H}_{19} \mathrm{~N}_{6} \mathrm{OS} 427.13356$, found 427.13354 .

N-(2-Fluorophenyl)-2-(3-(4-methylthiazol-2-yl)-4-(quinoxalin-6-yl)-1H-pyrazol-1-yl)acetamide (14f) : Yield 70\%; mp 197.5-200.0C; HPLC purity: 96.75\% (acetonitrile: 45\%); $\left.{ }^{1} \mathrm{H} \mathrm{NMR} \mathrm{(300} \mathrm{MHz}_{2} \mathrm{CDCl}_{3}\right)$ $\delta 8.89(\mathrm{~s}, 1 \mathrm{H}) 8.85(\mathrm{~d}, J=6.0 \mathrm{~Hz}, 2 \mathrm{H}), 8.32(\mathrm{~s}, 1 \mathrm{H}), 8.28(\mathrm{~d}, J=9.0 \mathrm{~Hz}, 1 \mathrm{H}), 8.11(\mathrm{~d}, J=9.0 \mathrm{~Hz}, 1 \mathrm{H}), 8.04$ $(\mathrm{d}, J=9.0 \mathrm{~Hz}, 1 \mathrm{H}), 7.85(\mathrm{~s}, 1 \mathrm{H}), 7.15-7.06(\mathrm{~m}, 3 \mathrm{H}), 6.92(\mathrm{~s}, 1 \mathrm{H}), 5.09(\mathrm{~s}, 2 \mathrm{H}), 2.43(\mathrm{~s}, 3 \mathrm{H}) ;{ }^{13} \mathrm{C}$ NMR $(75$ $\left.\mathrm{MHz}_{1} \mathrm{CDCl}_{3}\right) \delta 164.07,158.99,153.61,152.71(\mathrm{~d}, J=243.75 \mathrm{~Hz}), 145.17,145.07,144.79,142.91,142.45$, 133.39, 132.77, 132.22, 128.95, 128.89, 128.76, $125.55(\mathrm{~d}, J=9.8 \mathrm{~Hz}), 125.21(\mathrm{~d}, J=7.5 \mathrm{~Hz}), 124.56(\mathrm{~d}, J=$ $3.8 \mathrm{~Hz}), 121.80,121.67,115.02(\mathrm{~d}, J=19.5 \mathrm{~Hz}), 55.97,17.12 ; \mathrm{HRMS}-\mathrm{ESI}(\mathrm{m} / \mathrm{z}):[\mathrm{M}+\mathrm{H}]^{+}$calcd for $\mathrm{C}_{23} \mathrm{H}_{18} \mathrm{FN}_{6} \mathrm{OS} 445.12413$, found 445.12405.

N-(3-Fluorophenyl)-2-(3-(4-methylthiazol-2-yl)-4-(quinoxalin-6-yl)-1H-pyrazol-1-yl)acetamide (14g) : Yield 81\%; mp 212.1-213.5 C; HPLC purity: 100.00\% (acetonitrile: $45 \%)$; ${ }^{1} \mathrm{H}$ NMR $(300 \mathrm{MHz}$, $\left.\mathrm{CDCl}_{3}\right) \delta 9.41(\mathrm{~s}, 1 \mathrm{H}), 8.85($ br s, $2 \mathrm{H}), 8.27(\mathrm{~s}, 1 \mathrm{H}), 8.10(\mathrm{~d}, J=9.0 \mathrm{~Hz}, 1 \mathrm{H}), 8.02(\mathrm{~s}, 1 \mathrm{H}), 7.95(\mathrm{~d}, J=9.0$ $\mathrm{Hz}, 1 \mathrm{H}), 7.87(\mathrm{~s}, 1 \mathrm{H}), 7.52(\mathrm{~d}, J=9.0 \mathrm{~Hz}, 1 \mathrm{H}), 7.23(\mathrm{~d}, J=9.0 \mathrm{~Hz}, 1 \mathrm{H}), 6.90(\mathrm{~s}, 1 \mathrm{H}), 6.81(\mathrm{~d}, J=6.0 \mathrm{~Hz}$, $1 \mathrm{H}), 5.16(\mathrm{~s}, 2 \mathrm{H}), 2.43(\mathrm{~s}, 3 \mathrm{H}) ;{ }^{13} \mathrm{C} \mathrm{NMR}\left(75 \mathrm{MHz}, \mathrm{CDCl}_{3} / \mathrm{CD}_{3} \mathrm{OD}\right) \delta 168.83,167.13,166.78(\mathrm{~d}, J=243.0$ $\mathrm{Hz}), 163.54,156.91,149.04,148.52,147.19,146.58,145.91,143.17$ (d, J = 9.7 Hz), 138.13, 136.26, 133.97 $(\mathrm{d}, J=9.5 \mathrm{~Hz}), 132.51,132.16,125.03,119.20,118.66,115.09(\mathrm{~d}, J=21.3 \mathrm{~Hz}), 111.24(\mathrm{~d}, J=27.0 \mathrm{~Hz}), 59.22$, 20.44; HRMS-ESI (m/z): [M+H] $]^{+}$calcd for $\mathrm{C}_{23} \mathrm{H}_{18} \mathrm{FN}_{6} \mathrm{OS} 445.12413$, found 445.12415.

N-(3-Cyanophenyl)-2-(3-(4-methylthiazol-2-yl)-4-(quinoxalin-6-yl)-1H-pyrazol-1-yl)acetamide (14h) : Yield 74\%; mp 222.3-223.0 ${ }^{\circ} \mathrm{C}$; HPLC purity: 95.14\% (acetonitrile: $\left.45 \%\right) ;{ }^{1} \mathrm{H}$ NMR $(300 \mathrm{MHz}$, $\left.\mathrm{CDCl}_{3} / \mathrm{DMSO}-d_{6}\right) \delta 10.48(\mathrm{~s}, 1 \mathrm{H}), 8.76(\mathrm{~d}, J=6.0 \mathrm{~Hz}, 2 \mathrm{H}), 8.28(\mathrm{~s}, 1 \mathrm{H}), 8.04-7.95(\mathrm{~m}, 4 \mathrm{H}), 7.75(\mathrm{~d}, J=9.0$ $\mathrm{Hz}, 1 \mathrm{H}), 7.38(\mathrm{~d}, J=6.0 \mathrm{~Hz}, 1 \mathrm{H}), 7.32(\mathrm{t}, J=6.0 \mathrm{~Hz}, 1 \mathrm{H}), 6.84(\mathrm{~s}, 1 \mathrm{H}), 5.08(\mathrm{~s}, 2 \mathrm{H}), 2.32(\mathrm{~s}, 3 \mathrm{H}) ;{ }^{13} \mathrm{C} \mathrm{NMR}$ $\left(75 \mathrm{MHz}, \mathrm{DMSO}-d_{6}\right) \delta 166.11,160.40,152.90,146.42,145.74,142.95,142.79,141.84,139.73,134.79$, 134.25, 132.08, 130.93, 128.87, 128.11, 127.82, 124.32, 122.44, 119.87, 119.04, 115.33, 112.21, 55.37, 17.36; HRMS-ESI (m/z): $[\mathrm{M}+\mathrm{H}]^{+}$calcd for $\mathrm{C}_{24} \mathrm{H}_{18} \mathrm{~N}_{7} \mathrm{OS} 452.12881$, found 452.12878 . 
N-Phenyl-2-(3-(pyrimidin-4-yl)-4-(quinoxalin-6-yl)-1H-pyrazol-1- yl)acetamide (22a): Yield 61\%; mp 170.3-172.5 ${ }^{\circ}$; HPLC purity: 99.97\% (acetonitrile: 30\%); ${ }^{1} \mathrm{H}$ NMR (300 MHz, CDCl $) \delta 9.14(\mathrm{~s}, 1 \mathrm{H}), 8.85$ $(\mathrm{s}, 2 \mathrm{H}), 8.71(\mathrm{~d}, J=6.0 \mathrm{~Hz}, 1 \mathrm{H}), 8.65(\mathrm{~s}, 1 \mathrm{H}), 8.13(\mathrm{~d}, J=3.0 \mathrm{~Hz}, 1 \mathrm{H}), 8.08(\mathrm{~d}, J=6.0 \mathrm{~Hz}, 1 \mathrm{H}), 7.86(\mathrm{~s}, 1 \mathrm{H})$, $7.78(\mathrm{dd}, J=9.0,3.0 \mathrm{~Hz}, 1 \mathrm{H}), 7.67(\mathrm{~d}, J=6.0 \mathrm{~Hz}, 1 \mathrm{H}), 7.48(\mathrm{~d}, J=9.0 \mathrm{~Hz}, 2 \mathrm{H}), 7.30(\mathrm{~d}, J=6.0 \mathrm{~Hz}, 1 \mathrm{H}), 7.11$ $(\mathrm{t}, J=9.0 \mathrm{~Hz}, 1 \mathrm{H}), 5.12(\mathrm{~s}, 2 \mathrm{H}) ;{ }^{13} \mathrm{C} \mathrm{NMR}\left(125 \mathrm{MHz}, \mathrm{CDCl}_{3}\right) \delta 163.83,159.00,158.62,157.47,147.42$, $145.43,145.05,143.00,142.46,136.79,133.78$, 133.19, 131.97, 129.31, 129.14 (2C), 128.86, 125.19, 123.29, 120.22 (2C), 119.02, 56.24. HRMS-ESI (m/z): $[\mathrm{M}+\mathrm{H}]+$ calcd for $\mathrm{C}_{23} \mathrm{H}_{18} \mathrm{~N}_{7} \mathrm{O} 408.15673$, found 408.15622.

N-(2-Fluorophenyl)-2-(3-(pyrimidin-4-yl)-4-(quinoxalin-6-yl)-1H-pyrazol-1-yl)acetamide(22b): Yield 58\%; mp 192.3-194.5 C; HPLC purity: 99.97\% (acetonitrile: 30\%); ${ }^{1} \mathrm{H}$ NMR (300 MHz, CDCl $) \delta 9.10$ (s, 1H), 9.02 (br s, 1H, NH), $8.84(\mathrm{~s}, 2 \mathrm{H}), 8.77(\mathrm{~d}, J=6.0 \mathrm{~Hz}, 1 \mathrm{H}), 8.29(\mathrm{t}, J=7.5 \mathrm{~Hz}, 1 \mathrm{H}), 8.15(\mathrm{~d}, J=3.0$ $\mathrm{Hz}, 1 \mathrm{H}), 8.10(\mathrm{~d}, J=6.0 \mathrm{~Hz}, 1 \mathrm{H}), 7.85-7.77(\mathrm{~m}, 3 \mathrm{H}), 7.16-7.05(\mathrm{~m}, 3 \mathrm{H}), 5.13(\mathrm{~s}, 2 \mathrm{H}) ;{ }^{13} \mathrm{C} \mathrm{NMR}(125 \mathrm{MHz}$, $\left.\mathrm{CDCl}_{3}\right) \delta 163.72,158.86,158.57,157.19,152.56(\mathrm{~d}, J=244.0 \mathrm{~Hz}), 147.57,145.27,144.95,142.90,142.46$, 133.88, 133.31, 132.24, 129.07, 128.83, $125.55(\mathrm{~d}, J=10.2 \mathrm{~Hz}), 125.22(\mathrm{~d}, J=7.7 \mathrm{~Hz}), 124.73(\mathrm{~d}, J=3.6 \mathrm{~Hz})$, 123.45, 121.60, 118.80, 114.99 (d, $J=19.0 \mathrm{~Hz}$ ), 56.13; HRMS (ESI) m/z calcd for $\mathrm{C}_{23} \mathrm{H}_{17} \mathrm{FN} \mathrm{N}_{7} \mathrm{O} 426.14731$, found 426.14719 .

N-(3-Cyanophenyl)-2-(3-(pyrimidin-4-yl)-4-(quinoxalin-6-yl)-1H-pyrazol- 1-yl)acetamide (22d) : Yield 65\%; mp 178.3-180.5 ${ }^{\circ} \mathrm{C}$; HPLC purity: 99.27\% (acetonitrile: 30\%); ${ }^{1} \mathrm{H}$ NMR (300 MHz, DMSOd6) $\delta 10.86(\mathrm{~s}, 1 \mathrm{H}), 9.03(\mathrm{~s}, 1 \mathrm{H}), 8.95-8.93(\mathrm{~m}, 2 \mathrm{H}), 8.85(\mathrm{~d}, J=6.0 \mathrm{~Hz}, 1 \mathrm{H}), 8.39(\mathrm{~s}, 1 \mathrm{H}), 8.11(\mathrm{~s}, 2 \mathrm{H}), 8.06$ $(\mathrm{d}, J=9.0 \mathrm{~Hz}, 1 \mathrm{H}), 7.91-7.88(\mathrm{~m}, 3 \mathrm{H}), 7.59-7.58(\mathrm{~m}, 2 \mathrm{H}), 5.28(\mathrm{~s}, 2 \mathrm{H}) ;{ }^{13} \mathrm{C}$ NMR $(125 \mathrm{MHz}, \mathrm{DMSO}-$ $\left.d_{6} / \mathrm{CD}_{3} \mathrm{OD}\right) \delta 165.93,159.82,157.96,157.08,145.76,145.46,144.96,142.54,141.84,139.25,135.22,134.16$, 132.45, 130.03, 128.20, 127.82, 127.49, 123.96, 122.55, 122.17, 119.09, 118.18, 112.55, 54.91; HRMS-ESI (m/z): $[\mathrm{M}+\mathrm{H}]+$ calcd for $\mathrm{C}_{24} \mathrm{H}_{17} \mathrm{~N}_{8} \mathrm{O} 433.15198$, found 433.15179 .

2-(5-(6-(Dimethylamino)pyridin-2-yl)-4-(quinoxalin-6-yl)-1H-pyrazol-1-yl)-N-phenylacetamide (15a) : Yield 10\%; 145.4-147.5 ${ }^{\circ} \mathrm{C} ;{ }^{1} \mathrm{H}$ NMR (300 MHz, $\left.\mathrm{CDCl}_{3}\right) \delta 8.81(\mathrm{~d}, J=6.0 \mathrm{~Hz}, 2 \mathrm{H}), 8.22(\mathrm{~s}, 1 \mathrm{H}), 8.09$ (s, 1H), 8.02-7.99 (m, 2H), $7.69(\mathrm{dd}, J=9.0,3.0 \mathrm{~Hz}, 1 \mathrm{H}), 7.49(\mathrm{~d}, J=9.0 \mathrm{~Hz}, 2 \mathrm{H}), 7.34-7.28(\mathrm{~m}, 3 \mathrm{H}), 7.08$ $(\mathrm{t}, J=9.0 \mathrm{~Hz}, 1 \mathrm{H}), 6.52(\mathrm{~d}, J=9.0 \mathrm{~Hz}, 1 \mathrm{H}), 6.45(\mathrm{~d}, J=6.0 \mathrm{~Hz}, 1 \mathrm{H}), 5.17(\mathrm{~s}, 2 \mathrm{H}), 3.07(\mathrm{~s}, 6 \mathrm{H})$; HRMS-ESI $(\mathrm{m} / \mathrm{z}):[\mathrm{M}+\mathrm{H}]^{+}$calcd for $\mathrm{C}_{26} \mathrm{H}_{24} \mathrm{~N}_{7} \mathrm{O} 450.20368$, found 450.20364 .

2-(5-(6-(Dimethylamino)pyridin-2-yl)-4-(quinoxalin-6-yl)-1H-pyrazol-1-yl)-N-(2-

fluorophenyl)acetamide (15b): $\quad$ Yield 13\%; mp 130.2-133.0 ${ }^{\circ} \mathrm{C} ;{ }^{1} \mathrm{H} \mathrm{NMR}\left(300 \mathrm{MHz}, \mathrm{CDCl}_{3}\right) \delta 8.81(\mathrm{~d}$, $J=6.0 \mathrm{~Hz}, 2 \mathrm{H}), 8.45(\mathrm{~s}, 1 \mathrm{H}), 8.30(\mathrm{t}, J=7.5 \mathrm{~Hz}, 1 \mathrm{H}), 8.09(\mathrm{~s}, 1 \mathrm{H}), 8.01-7.98(\mathrm{~m}, 2 \mathrm{H}), 7.67(\mathrm{dd}, J=9.0,3.0$ $\mathrm{Hz}, 1 \mathrm{H}), 7.33(\mathrm{t}, J=9.0 \mathrm{~Hz}, 1 \mathrm{H}), 7.14-6.95(\mathrm{~m}, 3 \mathrm{H}), 6.51(\mathrm{~d}, J=6.0 \mathrm{~Hz}, 1 \mathrm{H}), 5.24(\mathrm{~s}, 2 \mathrm{H}), 3.07$ (s, 6H); HRMS-ESI (m/z): [M+H] $]^{+}$calcd for $\mathrm{C}_{26} \mathrm{H}_{23} \mathrm{FN}_{7} \mathrm{O} 468.19426$, found 468.19406.

2-(5-(6-(Dimethylamino)pyridin-2-yl)-4-(quinoxalin-6-yl)-1H-pyrazol-1-yl)-N-(3fluorophenyl)acetamide (15c): Yield 15\%; mp 146.5-147.6 ${ }^{\circ} \mathrm{C} ;{ }^{1} \mathrm{H}$ NMR $\left(300 \mathrm{MHz}, \mathrm{CDCl}_{3}\right) \delta 8.81(\mathrm{~d}$, $J=3.0 \mathrm{~Hz}, 2 \mathrm{H}), 8.41(\mathrm{~s}, 1 \mathrm{H}), 8.09(\mathrm{~s}, 1 \mathrm{H}), 8.00(\mathrm{~d}, J=9.0 \mathrm{~Hz}, 2 \mathrm{H}), 7.68(\mathrm{~d}, J=9.0,3.0 \mathrm{~Hz}, 1 \mathrm{H}), 7.50(\mathrm{~d}, J$ $=9.0 \mathrm{~Hz}, 1 \mathrm{H}), 7.35(\mathrm{t}, J=7.5 \mathrm{~Hz}, 1 \mathrm{H}), 7.23(\mathrm{t}, J=9.0 \mathrm{~Hz}, 1 \mathrm{H}), 7.11(\mathrm{~d}, J=9.0 \mathrm{~Hz}, 1 \mathrm{H}), 6.81(\mathrm{t}, J=9.0 \mathrm{~Hz}$, $1 \mathrm{H}), 6.53(\mathrm{~d}, J=9.0 \mathrm{~Hz}, 1 \mathrm{H}), 6.45(\mathrm{~d}, J=6.0 \mathrm{~Hz}, 1 \mathrm{H}), 5.16(\mathrm{~s}, 2 \mathrm{H}), 3.07(\mathrm{~s}, 6 \mathrm{H}) ;$ HRMS-ESI $(\mathrm{m} / \mathrm{z}):[\mathrm{M}+\mathrm{H}]^{+}$ calcd for $\mathrm{C}_{26} \mathrm{H}_{23} \mathrm{FN}_{7} \mathrm{O} 468.19426$, found 468.19427 .

N-(3-Cyanophenyl)-2-(5-(6-(dimethylamino)pyridin-2-yl)-4-(quinoxalin-6-yl)-1H-pyrazol-1yl)acetamide (15d): $\quad$ Yield 14\%; mp 145.5-148.0 ${ }^{\circ} \mathrm{C} ;{ }^{1} \mathrm{H}$ NMR $\left(300 \mathrm{MHz}, \mathrm{CDCl}_{3}\right) \delta 8.81(\mathrm{~d}, \mathrm{~J}=3.0 \mathrm{~Hz}$, $2 \mathrm{H}), 8.63(\mathrm{~s}, 1 \mathrm{H}), 8.08(\mathrm{~d}, J=3.0 \mathrm{~Hz}, 1 \mathrm{H}), 8.02-7.96(\mathrm{~m}, 3 \mathrm{H}), 7.67(\mathrm{~d}, J=9.0 \mathrm{~Hz}, 2 \mathrm{H}), 7.43-7.33(\mathrm{~m}, 3 \mathrm{H})$, $6.54(\mathrm{~d}, J=9.0 \mathrm{~Hz}, 1 \mathrm{H}), 6.43(\mathrm{~d}, J=9.0 \mathrm{~Hz}, 1 \mathrm{H}), 5.18(\mathrm{~s}, 2 \mathrm{H}), 3.07(\mathrm{~s}, 6 \mathrm{H}) ;$ HRMS-ESI $(\mathrm{m} / \mathrm{z}):[\mathrm{M}+\mathrm{H}]^{+}$calcd for $\mathrm{C}_{27} \mathrm{H}_{23} \mathrm{~N}_{8} \mathrm{O} 475.19893$, found 475.19891 .

2-(5-(4-Methylthiazol-2-yl)-4-(quinoxalin-6-yl)-1H-pyrazol-1-yl)-N-phenylacetamide (15e) : Yield $8 \% ;{ }^{1} \mathrm{H}$ NMR $\left(300 \mathrm{MHz}, \mathrm{CDCl}_{3}\right) \delta 9.64(\mathrm{~s}, 1 \mathrm{H}), 8.90(\mathrm{~s}, 2 \mathrm{H}), 8.14(\mathrm{~d}, J=6.0 \mathrm{~Hz}, 1 \mathrm{H}), 8.04(\mathrm{~s}, 4 \mathrm{H}), 7.83-$ 
$7.65(\mathrm{~m}, 1 \mathrm{H}), 7.60(\mathrm{~d}, J=6.0 \mathrm{~Hz}, 1 \mathrm{H}), 7.39-7.27(\mathrm{~m}, 2 \mathrm{H}), 7.14(\mathrm{~d}, J=6.0 \mathrm{~Hz}, 1 \mathrm{H}), 5.29(\mathrm{~s}, 2 \mathrm{H}), 2.60$ (s, $3 \mathrm{H})$; HRMS-ESI (m/z): $[\mathrm{M}+\mathrm{H}]^{+}$calcd for $\mathrm{C}_{23} \mathrm{H}_{19} \mathrm{~N}_{6} \mathrm{OS} 427.13356$, found 427.13361 .

N-(2-Fluorophenyl)-2-(5-(4-methylthiazol-2-yl)-4-(quinoxalin-6-yl)-1H-pyrazol-1-yl)acetamide (15f) : $\quad$ Yield 7\%; ${ }^{1} \mathrm{H}$ NMR $\left(300 \mathrm{MHz}, \mathrm{CDCl}_{3}\right) \delta 9.66(\mathrm{~s}, 1 \mathrm{H}), 8.86($ br s, 2H), $8.37(\mathrm{t}, \mathrm{J}=9.0 \mathrm{~Hz}, 1 \mathrm{H}), 8.13-$ $8.09(\mathrm{~m}, 2 \mathrm{H}), 7.87(\mathrm{~s}, 1 \mathrm{H}), 7.73(\mathrm{dd}, J=9.0,3.0 \mathrm{~Hz}, 1 \mathrm{H}), 7.16-7.03(\mathrm{~m}, 3 \mathrm{H}), 6.98(\mathrm{~s}, 1 \mathrm{H}), 5.33(\mathrm{~s}, 2 \mathrm{H}), 2.57$ (s, 3H); HRMS-ESI (m/z): [M+H] $]^{+}$calcd for $\mathrm{C}_{23} \mathrm{H}_{18} \mathrm{FN}_{6} \mathrm{OS} 445.12413$, found 445.12418 .

N-(3-Fluorophenyl)-2-(5-(4-methylthiazol-2-yl)-4-(quinoxalin-6-yl)-1H-pyrazol-1-yl)acetamide (15g) : $\quad$ Yield 7\%; ${ }^{1} \mathrm{H}$ NMR $\left(300 \mathrm{MHz}, \mathrm{CDCl}_{3}\right) \delta 9.98(\mathrm{~s}, 1 \mathrm{H}), 8.86$ (br s, 2H), $8.14(\mathrm{~d}, J=9.0 \mathrm{~Hz}, 1 \mathrm{H}), 8.01$ (br s, 2H), $7.87(\mathrm{~s}, 1 \mathrm{H}), 7.72(\mathrm{~d}, J=9.0 \mathrm{~Hz}, 1 \mathrm{H}), 7.55(\mathrm{~d}, J=9.0 \mathrm{~Hz}, 1 \mathrm{H}), 7.25$ (br s, 1H), 7.03 (br s, $1 \mathrm{H}), 6.81$ $(\mathrm{t}, J=9.0 \mathrm{~Hz}, 1 \mathrm{H}), 5.22(\mathrm{~s}, 2 \mathrm{H}), 2.59(\mathrm{~s}, 3 \mathrm{H})$; HRMS-ESI $(\mathrm{m} / \mathrm{z}):[\mathrm{M}+\mathrm{H}]^{+}$calcd for $\mathrm{C}_{23} \mathrm{H}_{18} \mathrm{FN}_{6} \mathrm{OS} 445.12413$, found 445.12408 .

N-(3-Cyanophenyl)-2-(5-(4-methylthiazol-2-yl)-4-(quinoxalin-6-yl)-1H-pyrazol-1-yl)acetamide (15h) : Yield 9\%; ${ }^{1} \mathrm{H}$ NMR (300 MHz, $\left.\mathrm{CDCl}_{3}\right) \delta 10.43(\mathrm{~s}, 1 \mathrm{H}), 8.75$ (br s, 2H), $8.36(\mathrm{~d}, J=3.0 \mathrm{~Hz}, 1 \mathrm{H}), 8.26(\mathrm{~d}$, $J=9.0,1 \mathrm{H}), 8.06-7.91(\mathrm{~m}, 3 \mathrm{H}), 7.74-7.6(\mathrm{~m}, 2 \mathrm{H}), 7.37-7.26(\mathrm{~m}, 2 \mathrm{H}), 5.42(\mathrm{~s}, 2 \mathrm{H}), 2.34(\mathrm{~s}, 3 \mathrm{H})$; HRMSESI (m/z): $[\mathrm{M}+\mathrm{H}]^{+}$calcd for $\mathrm{C}_{24} \mathrm{H}_{18} \mathrm{~N}_{7} \mathrm{OS} 452.12881$, found 452.12881

N-Phenyl-2-(5-(pyrimidin-4-yl)-4-(quinoxalin-6-yl)-2,3-dihydro-1H-pyrazol-1-yl)acetamide (23a) : Yield 10\%; HPLC purity: 96.43\% (acetonitrile: $30 \%) ;{ }^{1} \mathrm{H}$ NMR $\left(300 \mathrm{MHz}, \mathrm{CDCl}_{3}\right) \delta 9.43(\mathrm{~s}, 1 \mathrm{H}), 8.87(\mathrm{~s}$, $2 \mathrm{H}), 8.80(\mathrm{~s}, 1 \mathrm{H}), 8.66(\mathrm{~d}, J=6.0 \mathrm{~Hz}, 1 \mathrm{H}), 8.11(\mathrm{~d}, J=9.0 \mathrm{~Hz}, 1 \mathrm{H}), 8.05(\mathrm{~s}, 1 \mathrm{H}), 7.95(\mathrm{~s}, 1 \mathrm{H}), 7.62(\mathrm{dd}, J=$ 9.0, 3.0 Hz, 1H), $7.53(\mathrm{~d}, J=6.0 \mathrm{~Hz}, 2 \mathrm{H}), 7.33(\mathrm{t}, J=7.5 \mathrm{~Hz}, 2 \mathrm{H}), 7.20(\mathrm{dd}, J=6.0,3.0 \mathrm{~Hz}, 1 \mathrm{H}), 7.13(\mathrm{t}, J=$ $7.5 \mathrm{~Hz}, 1 \mathrm{H}), 5.29$ (s, 2H); HRMS-ESI (m/z): [M+H]+ calcd for $\mathrm{C}_{23} \mathrm{H}_{18} \mathrm{~N}_{7} \mathrm{O}$ 408.15673, found 408.15698.

N-(2-Fluorophenyl)-2-(5-(pyrimidin-4-yl)-4-(quinoxalin-6-yl)-2,3-dihydro-1H-pyrazol-1-

yl)acetamide (23b): Yield 7\%; HPLC purity: 99.29\% (acetonitrile: 30\%); $\left.{ }^{1} \mathrm{H} \mathrm{NMR} \mathrm{(300} \mathrm{MHz}_{2} \mathrm{CDCl}_{3}\right)$ $\delta 9.55(\mathrm{~s}, 1 \mathrm{H}), 9.45(\mathrm{~s}, 1 \mathrm{H}), 8.86(\mathrm{~s}, 2 \mathrm{H}), 8.65(\mathrm{~d}, J=6.0 \mathrm{~Hz}, 1 \mathrm{H}), 8.34(\mathrm{t}, J=9.0 \mathrm{~Hz}, 1 \mathrm{H}), 8.11(\mathrm{~d}, J=9.0$ $\mathrm{Hz}, 1 \mathrm{H}), 8.06(\mathrm{~s}, 1 \mathrm{H}), 7.94(\mathrm{~s}, 1 \mathrm{H}), 7.62(\mathrm{dd}, J=9.0,3.0 \mathrm{~Hz}, 1 \mathrm{H}), 7.19(\mathrm{~d}, \mathrm{~J}=6.0 \mathrm{~Hz}, 1 \mathrm{H}), 7.15-7.05(\mathrm{~m}$, $3 \mathrm{H}), 5.31$ (s, 2H); HRMS-ESI (m/z): $[\mathrm{M}+\mathrm{H}]+$ calcd for $\mathrm{C}_{23} \mathrm{H}_{17} \mathrm{FN} 7 \mathrm{O} 426.14731$, found 426.14783.

N-(3-Cyanophenyl)-2-(5-(pyrimidin-4-yl)-4-(quinoxalin-6-yl)-2,3-dihydro-1H-pyrazol-1yl)acetamide (23d): Yield 13\%; HPLC purity: 97.98\% (acetonitrile: 45\%); $\left.{ }^{1} \mathrm{H} \mathrm{NMR} \mathrm{(300} \mathrm{MHz}_{2} \mathrm{CDCl}_{3}\right)$ $\delta 10.04$ (s, 1H), 9.25 (s, 1H), 8.78 (br s, 2H), 8.54(s, 1H), 7.96 (br s, 3H), 7.89-7.81 (m, 2H), 7.69 (br s, 1H), 7.58 (br s, 1H), 7.26 (s, 1H), 7.19 (s, 1H), 5.44 (s, 2H); HRMS (ESI) m/z calcd for $\mathrm{C}_{24} \mathrm{H}_{17} \mathrm{~N}_{8} \mathrm{O}$ 433.15198, found 433.15216 .

3.1.5. General procedure for the preparation of 2-(3-(6-(dimethylamino)pyridin-2-yl)-4-(quinoxalin6-yl)-1H-pyrazol-1-yl)-N-phenylethanethioamide 16a-d, 2-(3-(4-methylthiazol-2-yl)-4-(quinoxalin6-yl)-1H-pyrazol-1-yl)-N-phenylethanethioamide 16e-h or N-phenyl-2-(3-(pyrimidin-4-yl)-4(quinoxalin-6-yl)-1H-pyrazol-1-yl)ethanethioamide (24b, 24d)

A stirred mixture of $\mathbf{1 4 a}-\mathbf{h}, \mathbf{2 2} \mathbf{b}$ or $\mathbf{2 2 d}(0.34 \mathrm{mmol})$, Lawesson's reagent $(0.34 \mathrm{mmol})$, and anhydrous DME $(5 \mathrm{~mL})$ in a dry sealed tube was heated at $85^{\circ} \mathrm{C}$ for $12 \mathrm{~h}$. After cooled to room temperature, the solvent was evaporated to dryness under reduced pressure, and the residue was purified by silica gel column chromatography (dichloromethane/methanol, 100:1) to give the titled compounds $\mathbf{1 6 a - h ,} \mathbf{2 4 b}$ or $\mathbf{2 4 d}$ as a light yellow solid.

2-(3-(6-(Dimethylamino)pyridin-2-yl)-4-(quinoxalin-6-yl)-1H-pyrazol-1-yl)-Nphenylethanethioamide (16a): Yield 45\%; mp 182.0-184.0 ${ }^{\circ} \mathrm{C}$; HPLC purity: 96.95\% (acetonitrile: 40\%); ${ }^{1} \mathrm{H}$ NMR (300 MHz, $\left.\mathrm{CDCl}_{3}\right) \delta 10.79(\mathrm{~s}, 1 \mathrm{H}), 8.82(\mathrm{~d}, J=6.0 \mathrm{~Hz}, 2 \mathrm{H}), 8.15(\mathrm{~s}, 1 \mathrm{H}), 8.03(\mathrm{~d}, J=9.0$ $\mathrm{Hz}, 1 \mathrm{H}), 7.82-7.70(\mathrm{~m}, 3 \mathrm{H}), 7.52(\mathrm{t}, J=7.5 \mathrm{~Hz}, 2 \mathrm{H}), 7.39(\mathrm{t}, J=7.5 \mathrm{~Hz}, 2 \mathrm{H}), 7.26(\mathrm{~d}, J=9.0 \mathrm{~Hz}, 1 \mathrm{H}), 7.09$ $(\mathrm{d}, J=9.0 \mathrm{~Hz}, 1 \mathrm{H}), 6.49(\mathrm{~d}, J=9.0 \mathrm{~Hz}, 1 \mathrm{H}), 5.44(\mathrm{~s}, 2 \mathrm{H}), 2.74(\mathrm{~s}, 6 \mathrm{H}) ;{ }^{13} \mathrm{C} \mathrm{NMR}\left(75 \mathrm{MHz}, \mathrm{CDCl}_{3}\right) \delta 192.76$, $167.73,145.14,144.56,142.96,142.06,138.24,138.00,132.68,132.39,132.31,130.93(2 \mathrm{C}), 128.90,128.85$ 
(2C), 128.60, 128.25, 127.00, 123.04, 121.71, 109.87, 105.56, 65.58, 37.67 (2C); HRMS-ESI (m/z): [M+H] ${ }^{+}$ calcd for $\mathrm{C}_{26} \mathrm{H}_{24} \mathrm{~N}_{7} \mathrm{~S} 466.18084$, found 466.18082 .

2-(3-(6-(Dimethylamino)pyridin-2-yl)-4-(quinoxalin-6-yl)-1H-pyrazol-1-yl)-N-(2fluorophenyl)ethanethioamide (16b) : Yield 43\%; mp 88.3-91.2。 $\mathrm{C}$; HPLC purity: 99.31\% (acetonitrile: 40\%); ${ }^{1} \mathrm{H}$ NMR $\left(300 \mathrm{MHz}, \mathrm{CDCl}_{3}\right) \delta 10.79(\mathrm{~s}, 1 \mathrm{H}), 8.82(\mathrm{~d}, J=6.0 \mathrm{~Hz}, 2 \mathrm{H}), 8.70(\mathrm{t}, J=7.5$ $\mathrm{Hz}, 1 \mathrm{H}), 8.16(\mathrm{~d}, J=3.0 \mathrm{~Hz}, 1 \mathrm{H}), 8.01(\mathrm{~d}, J=9.0 \mathrm{~Hz}, 1 \mathrm{H}), 7.82(\mathrm{dd}, J=9.0,3.0 \mathrm{~Hz}, 1 \mathrm{H}), 7.79(\mathrm{~s}, 1 \mathrm{H}), 7.53$ $(\mathrm{t}, J=7.5 \mathrm{~Hz}, 1 \mathrm{H}), 7.24-7.17(\mathrm{~m}, 4 \mathrm{H}), 6.46(\mathrm{~d}, J=9.0 \mathrm{~Hz}, 1 \mathrm{H}), 5.44(\mathrm{~s}, 2 \mathrm{H}), 2.64(\mathrm{~s}, 6 \mathrm{H}) ;{ }^{13} \mathrm{C} \mathrm{NMR}(125$ $\left.\mathrm{MHz}_{1} \mathrm{CDCl}_{3}\right) \delta 193.51,158.67,154.33(\mathrm{~d}, J=248.6 \mathrm{~Hz}), 151.59,149.39,145.06,144.48,142.98,142.07$, 137.80, 135.72, 132.94, 132.23, $128.36(\mathrm{~d}, J=18.0 \mathrm{~Hz}), 127.63(\mathrm{~d}, J=7.8 \mathrm{~Hz}), 126.72(\mathrm{~d}, J=10.0 \mathrm{~Hz}), 124.02$ $(\mathrm{d}, J=3.8 \mathrm{~Hz}), 123.79,121.91,115.48(\mathrm{~d}, J=19.1 \mathrm{~Hz}), 109.76,105.30,63.66,37.48$ (2C); HRMS-ESI (m/z): $[\mathrm{M}+\mathrm{H}]^{+}$calcd for $\mathrm{C}_{26} \mathrm{H}_{23} \mathrm{FN}_{7} \mathrm{~S} 484.17142$, found 484.17133 .

2-(3-(6-(Dimethylamino)pyridin-2-yl)-4-(quinoxalin-6-yl)-1H-pyrazol-1-yl)-N-(3-

fluorophenyl)ethanethioamide (16c) : Yield 44\%; mp 68.5-70.2 ${ }^{\circ}$; HPLC purity: 98.45\% (acetonitrile: $40 \%) ;{ }^{1} \mathrm{H}$ NMR $\left(300 \mathrm{MHz}, \mathrm{CDCl}_{3}\right) \delta 10.94(\mathrm{~s}, 1 \mathrm{H}), 8.82(\mathrm{~d}, J=6.0 \mathrm{~Hz}, 2 \mathrm{H}), 8.14(\mathrm{~d}, J=3.0$ $\mathrm{Hz}, 1 \mathrm{H}), 8.02(\mathrm{~d}, J=9.0 \mathrm{~Hz}, 1 \mathrm{H}), 7.88(\mathrm{~d}, J=9.0 \mathrm{~Hz}, 1 \mathrm{H}), 7.81-7.78(\mathrm{~m}, 2 \mathrm{H}), 7.52(\mathrm{t}, J=7.5 \mathrm{~Hz}, 1 \mathrm{H}), 7.42$ $(\mathrm{d}, J=9.0 \mathrm{~Hz}, 1 \mathrm{H}), 7.34(\mathrm{t}, J=9.0 \mathrm{~Hz}, 1 \mathrm{H}), 7.09(\mathrm{~d}, J=9.0 \mathrm{~Hz}, 1 \mathrm{H}), 6.96(\mathrm{t}, J=9.0 \mathrm{~Hz}, 1 \mathrm{H}), 6.47(\mathrm{~d}, J=9.0$ $\mathrm{Hz}, 1 \mathrm{H}), 5.40$ (s, 2H), $2.71(\mathrm{~s}, 6 \mathrm{H}) ;{ }^{13} \mathrm{C} \mathrm{NMR}\left(75 \mathrm{MHz}, \mathrm{CDCl}_{3}\right) \delta 192.94,164.11,159.68(\mathrm{~d}, J=175.7 \mathrm{~Hz})$, 148.85, 145.17, 144.61, 142.96, 142.08, $139.63(\mathrm{~d}, J=10.5 \mathrm{~Hz}), 138.03,135.26,133.85,132.50(\mathrm{~d}, J=15.0$ $\mathrm{Hz}), 130.06$ (d, J = 9.2 Hz), 128.67, 128.27, 121.74, 118.38 (d, J = 3.2 Hz), $113.74(\mathrm{~d}, J=21.2 \mathrm{~Hz}), 110.24$, 109.89, 105.66, 63.58, 37.69 (2C); HRMS-ESI (m/z): $[\mathrm{M}+\mathrm{H}]^{+}$calcd for $\mathrm{C}_{26} \mathrm{H}_{23} \mathrm{FN} 7 \mathrm{~S} 484.17142$, found 484.17133.

N-(3-Cyanophenyl)-2-(3-(6-(dimethylamino)pyridin-2-yl)-4-(quinoxalin-6-yl)-1H-pyrazol-1yl)ethanethioamide (16d): Yield 37\%; mp 108.5-110.0॰C; HPLC purity: $96.46 \%$ (acetonitrile: 40\%); ${ }^{1} \mathrm{H}$ NMR $\left(300 \mathrm{MHz}, \mathrm{CDCl}_{3}\right) \delta 11.13(\mathrm{~s}, 1 \mathrm{H}), 8.83(\mathrm{~d}, J=6.0 \mathrm{~Hz}, 2 \mathrm{H}), 8.26(\mathrm{~s}, 1 \mathrm{H}), 8.14(\mathrm{~s}, 1 \mathrm{H}), 8.01(\mathrm{t}, J=$ $9.0 \mathrm{~Hz}, 2 \mathrm{H}), 7.81-7.78(\mathrm{~m}, 2 \mathrm{H}), 7.54-7.49(\mathrm{~m}, 3 \mathrm{H}), 7.05(\mathrm{~d}, J=9.0 \mathrm{~Hz}, 1 \mathrm{H}), 6.49(\mathrm{~d}, J=9.0 \mathrm{~Hz}, 1 \mathrm{H}), 5.41$ $(\mathrm{s}, 2 \mathrm{H}), 2.73(\mathrm{~s}, 6 \mathrm{H}) ;{ }^{13} \mathrm{C}$ NMR $\left(75 \mathrm{MHz}, \mathrm{DMSO}-d_{6}\right) \delta 197.16,158.56,146.18,145.39,142.71,141.48$, $140.23,138.33,137.50,136.35,134.03,132.69,130.75,130.50,128.59,127.49,126.65,120.36,120.15$, 118.77, 111.89, 110.23, 105.33, 62.82, 39.12 (2C); HRMS-ESI (m/z): $[\mathrm{M}+\mathrm{H}]^{+}$calcd for $\mathrm{C}_{27} \mathrm{H}_{23} \mathrm{~N}_{8} \mathrm{~S}$ 491.17609, found 491.17609 .

2-(3-(4-Methylthiazol-2-yl)-4-(quinoxalin-6-yl)-1H-pyrazol-1-yl)-N-phenylethanethioamide(16e): Semi-solid; Yield 80\%; HPLC purity: 96.56\% (acetonitrile: 45\%); ${ }^{1} \mathrm{H}$ NMR (300 MHz, CDCl $) \delta 11.02$ $(\mathrm{s}, 1 \mathrm{H}), 8.91(\mathrm{br} \mathrm{s}, 2 \mathrm{H}), 8.29(\mathrm{~s}, 1 \mathrm{H}), 8.17(\mathrm{t}, J=9.0 \mathrm{~Hz}, 1 \mathrm{H}), 7.96-7.88(\mathrm{~m}, 3 \mathrm{H}), 7.38(\mathrm{t}, J=9.0 \mathrm{~Hz}, 2 \mathrm{H})$, 7.26 (b r s, 2H), 6.96 (s, 1H), $5.54(\mathrm{~s}, 2 \mathrm{H}), 2.57$ (s, 3H); ${ }^{3} \mathrm{C}$ NMR $\left(125 \mathrm{MHz}, \mathrm{CDCl}_{3}\right) \delta$ 192.07, 158.81, $153.81,145.31,145.10,144.93,142.98,142.53,138.17,133.19,132.62,132.07,129.16,129.07,128.99$ (2C), 127.12, $122.94(2 \mathrm{C}), 121.70,114.54,63.83,17.13$; HRMS-ESI $(\mathrm{m} / \mathrm{z}):[\mathrm{M}+\mathrm{H}]^{+}$calcd for $\mathrm{C}_{23} \mathrm{H}_{19} \mathrm{~N}_{6} \mathrm{~S}_{2}$ 443.11071, found 443.11072 .

N-(2-Fluorophenyl)-2-(3-(4-methylthiazol-2-yl)-4-(quinoxalin-6-yl)-1H-pyrazol-1yl)ethanethioamide (16f): Semi-solid; Yield 84\%; HPLC purity: 96.40\% (acetonitrile: $45 \%$ ); ${ }^{1} \mathrm{H}$ NMR $\left(300 \mathrm{MHz}, \mathrm{DMSO}-\mathrm{d}_{6}\right) \delta 11.79(\mathrm{~s}, 1 \mathrm{H}), 8.94(\mathrm{~d}, J=9.0 \mathrm{~Hz}, 2 \mathrm{H}), 8.50(\mathrm{~d}, J=9.0 \mathrm{~Hz}, 2 \mathrm{H}), 8.16(\mathrm{~d}, J=9.0 \mathrm{~Hz}$, $1 \mathrm{H}), 8.08(\mathrm{~d}, J=9.0 \mathrm{~Hz}, 1 \mathrm{H}), 7.73-7.61(\mathrm{~m}, 4 \mathrm{H}), 7.39-7.25(\mathrm{~m}, 2 \mathrm{H}), 5.48(\mathrm{~s}, 2 \mathrm{H}), 2.35(\mathrm{~s}, 3 \mathrm{H}) ;{ }^{13} \mathrm{C} \mathrm{NMR}$ $\left(75 \mathrm{MHz}, \mathrm{CDCl}_{3} / \mathrm{DMSO}-d_{6}\right) \delta$ 194.18, 167.96, 159.08, $154.96(\mathrm{~d}, J=248.25 \mathrm{~Hz}), 153.40,145.09,144.63$, 142.66, 142.09, 133.79, 132.61, 132.27, $131.08(\mathrm{~d}, J=14.4 \mathrm{~Hz}), 130.99,130.43,128.77(\mathrm{~d}, J=3.0 \mathrm{~Hz}), 128.60$ $(\mathrm{d}, J=8.3 \mathrm{~Hz}), 128.21(\mathrm{~d}, J=8.3 \mathrm{~Hz}), 125.28,115.68(\mathrm{~d}, J=19.4 \mathrm{~Hz}), 114.68,65.63,19.07$; HRMS-ESI $(\mathrm{m} / \mathrm{z}):[\mathrm{M}+\mathrm{H}]^{+}$calcd for $\mathrm{C}_{23} \mathrm{H}_{18} \mathrm{FN}_{6} \mathrm{~S}_{2} 461.10129$, found 461.10120 .

N-(3-Fluorophenyl)-2-(3-(4-methylthiazol-2-yl)-4-(quinoxalin-6-yl)-1H-pyrazol-1yl)ethanethioamide (16g): Semi-solid; Yield 88\%; HPLC purity: 96.37\% (acetonitrile: 45\%); ${ }^{1} \mathrm{H}$ NMR $\left(300 \mathrm{MHz}, \mathrm{DMSO}-\mathrm{d}_{6}\right) \delta 12.21(\mathrm{~s}, 1 \mathrm{H}), 8.93(\mathrm{~d}, J=9.0 \mathrm{~Hz}, 2 \mathrm{H}), 8.52(\mathrm{~s}, 1 \mathrm{H}), 8.48(\mathrm{~s}, 1 \mathrm{H}), 8.16(\mathrm{~d}, J=9.0$ 
$\mathrm{Hz}, 1 \mathrm{H}), 8.06(\mathrm{t}, J=9.0 \mathrm{~Hz}, 1 \mathrm{H}), 7.73-7.68(\mathrm{~m}, 2 \mathrm{H}), 7.50(\mathrm{~d}, J=9.0 \mathrm{~Hz}, 1 \mathrm{H}), 7.31(\mathrm{~s}, 1 \mathrm{H}), 7.14(\mathrm{~s}, 1 \mathrm{H})$, 5.43 (s, 2H), 2.34 (s, 3H); ${ }^{13} \mathrm{C} \mathrm{NMR}\left(75 \mathrm{MHz}, \mathrm{CDCl}_{3} / \mathrm{DMSO}_{-16}\right) \delta 197.82,166.35$ (d, J = 243.0 Hz), 163.66, 157.17, 149.06, 148.50, 147.52, 146.54, 145.81, 138.34, $136.12(\mathrm{~d}, J=17.5 \mathrm{~Hz}), 135.66,135.10(\mathrm{~d}, J=11.4$ $\mathrm{Hz}), 133.83(\mathrm{~d}, J=9.0 \mathrm{~Hz}), 132.68,132.34,124.62,122.40(\mathrm{~d}, J=2.3 \mathrm{~Hz}), 118.65,117.20(\mathrm{~d}, J=21.0 \mathrm{~Hz})$, 114.12, 69.57, 17.24; HRMS-ESI (m/z): $[\mathrm{M}+\mathrm{H}]^{+}$calcd for $\mathrm{C}_{23} \mathrm{H}_{18} \mathrm{FN}_{6} \mathrm{~S}_{2} 461.10129$, found 461.10132.

N-(3-Cyanophenyl)-2-(3-(4-methylthiazol-2-yl)-4-(quinoxalin-6-yl)-1H-pyrazol-1yl)ethanethioamide (16h): Semi-solid; Yield 89\%; HPLC purity: 96.31\% (acetonitrile: $45 \%$ ); ${ }^{1} \mathrm{H}$ NMR $\left(300 \mathrm{MHz}, \mathrm{DMSO}-\mathrm{d}_{6}\right) \delta 12.33(\mathrm{~s}, 1 \mathrm{H}), 8.93(\mathrm{~d}, J=9.0 \mathrm{~Hz}, 2 \mathrm{H}), 8.50(\mathrm{~d}, J=6.0 \mathrm{~Hz}, 2 \mathrm{H}), 8.44(\mathrm{~s}, 1 \mathrm{H}), 8.14-$ $8.06(\mathrm{~m}, 2 \mathrm{H}), 7.77(\mathrm{~d}, J=6.0 \mathrm{~Hz}, 1 \mathrm{H}), 7.69(\mathrm{t}, J=7.5 \mathrm{~Hz}, 1 \mathrm{H}), 7.31(\mathrm{~s}, 1 \mathrm{H}), 6.91(\mathrm{~s}, 1 \mathrm{H}), 5.45(\mathrm{~s}, 2 \mathrm{H}), 2.34$ (s, 3H); ${ }^{13} \mathrm{C}$ NMR (75 MHz, DMSO-d6) $\delta 196.70,160.48,152.89,146.42,145.73,143.12,142.80,141.82$, $140.22,135.10,134.31,132.08,130.75,130.48,128.87,128.53,128.08,126.60,119.71,118.76,115.34$, 111.90, 61.84, 17.36; HRMS-ESI (m/z): [M+H]+ calcd for $\mathrm{C}_{24} \mathrm{H}_{18} \mathrm{~N}_{7} \mathrm{~S}_{2} 468.10596$, found 468.10599.

N-(2-Fluorophenyl)-2-(3-(pyrimidin-4-yl)-4-(quinoxalin-6-yl)-1H-pyrazol-1-yl)ethanethioamide (24a): Yield 68\%; HPLC purity: 98.75\% (acetonitrile: 35\%); ${ }^{1} \mathrm{H} \mathrm{NMR}\left(300 \mathrm{MHz}, \mathrm{CDCl}_{3}\right) \delta 10.57(\mathrm{~s}, 1 \mathrm{H}$, $\mathrm{NH}), 9.12(\mathrm{~s}, 1 \mathrm{H}), 8.84(\mathrm{~s}, 2 \mathrm{H}), 8.78(\mathrm{~s}, 1 \mathrm{H}), 8.64(\mathrm{t}, J=7.5 \mathrm{~Hz}, 1 \mathrm{H}), 8.16(\mathrm{~s}, 1 \mathrm{H}), 8.08(\mathrm{~d}, J=9.0 \mathrm{~Hz}, 1 \mathrm{H})$, $7.92(\mathrm{~s}, 1 \mathrm{H}), 7.82(\mathrm{~d}, J=9.0 \mathrm{~Hz}, 2 \mathrm{H}), 7.23-7.10(\mathrm{~m}, 3 \mathrm{H}), 5.48(\mathrm{~s}, 2 \mathrm{H}) ;{ }^{13} \mathrm{C} \mathrm{NMR}\left(125 \mathrm{MHz}, \mathrm{CDCl}_{3}\right) \delta$ 192.31, 167.73 , 158.80, 157.49, $154.12(\mathrm{~d}, J=247.5 \mathrm{~Hz}), 147.81,145.36,145.01,142.94,142.47,133.77$, 133.11, 132.15, 130.92, 128.89, 128.85, $127.72(\mathrm{~d}, J=7.5 \mathrm{~Hz}), 126.62(\mathrm{~d}, J=10.0 \mathrm{~Hz}), 124.19(\mathrm{~d}, J=3.75$ $\mathrm{Hz}), 123.47,118.84,115.44(\mathrm{~d}, J=18.75 \mathrm{~Hz}), 65.58$; HRMS-ESI $(\mathrm{m} / \mathrm{z}):[\mathrm{M}+\mathrm{H}]^{+}$calcd for $\mathrm{C}_{23} \mathrm{H}_{17} \mathrm{FN}_{7} \mathrm{~S}$ 442.12447, found 442.12447 .

N-(3-Cyanophenyl)-2-(3-(pyrimidin-4-yl)-4-(quinoxalin-6-yl)-1H-pyrazol-1-yl)ethanethioamide (24b): Yield 50\%; HPLC purity: 99.68\% (acetonitrile: 35\%); ${ }^{1} \mathrm{H}$ NMR (300 MHz, CDCl $) \delta 10.57(\mathrm{~s}, 1 \mathrm{H}$, $\mathrm{NH}), 9.21(\mathrm{~s}, 1 \mathrm{H}), 8.88(\mathrm{~s}, 2 \mathrm{H}), 8.76(\mathrm{~d}, J=6.0 \mathrm{~Hz}, 1 \mathrm{H}), 8.27(\mathrm{~s}, 1 \mathrm{H}), 8.16-8.11(\mathrm{~m}, 2 \mathrm{H}), 7.91(\mathrm{br}, 2 \mathrm{H})$, $7.79(\mathrm{~d}, J=9.0 \mathrm{~Hz}, 1 \mathrm{H}), 7.64(\mathrm{~s}, 1 \mathrm{H}), 7.54-7.49(\mathrm{~m}, 2 \mathrm{H}), 5.50(\mathrm{~s}, 2 \mathrm{H}) ;{ }^{13} \mathrm{C} \mathrm{NMR}\left(125 \mathrm{MHz}, \mathrm{CDCl}_{3}\right) \delta$ 194.60, 159.15, 158.61, 157.07, 146.27, 145.21, 144.73, 142.88, 142.19, 139.77, 134.36, 133.27, 132.07, 129.72, $129.61,128.89,128.47,127.38,126.19,122.38,119.06,118.16,112.49,63.61 ;$ HRMS-ESI $(\mathrm{m} / \mathrm{z}):[\mathrm{M}+\mathrm{H}]+$ calcd for $\mathrm{C}_{24} \mathrm{H}_{17} \mathrm{~N}_{8} \mathrm{~S} 449.12914$, found 449.1285

\subsection{Kinase assay}

All protein kinases provided by ProQinase were expressed in Sf9 insect cells or in E.coli as recombinant GST-fusion proteins or His-tagged proteins, either as full-length or enzymatically active fragments. All kinases were obtained from human cDNAs and purified by either GSH-affinity chromatography or immobilized metal. The purity of the protein kinases was examined by SDSPAGE/Coomassie staining. The identity was checked by mass spectroscopy.

A radiometric protein kinase assay (33PanQinase ${ }^{\circledR}$ activity assay) was used for measuring the kinase activity of the two protein kinases. All kinase assays were performed in 96-well FlashPlates ${ }^{\mathrm{TM}}$ from PerkinElmer (Boston, MA, USA) in $50 \mu \mathrm{L}$ reaction volumes. The reaction cocktail was pipetted in four steps in the following order: $20 \mu \mathrm{L}$ of assay buffer (standard buffer), $5 \mu \mathrm{L}$ of ATP solution (in $\mathrm{H}_{2} \mathrm{O}$ ), $5 \mu \mathrm{L}$ of test compound (in 10\% DMSO), $20 \mu \mathrm{L}$ enzyme/substrate mix.

The assay for all protein kinases contained $70 \mathrm{mM}$ HEPES-NaOH pH 7.5, $3 \mathrm{mM} \mathrm{MgCl2,} 3 \mathrm{mM}$ MnCl2, $3 \mu \mathrm{M}$ Na-orthovanadate, $1.2 \mathrm{mM}$ DTT, $50 \mu \mathrm{g} / \mathrm{mL}$ PEG20000, ATP, [ $\left.\gamma^{-33} \mathrm{P}\right]-\mathrm{ATP}$, protein kinase, and substrate.

The reaction cocktail was incubated at $30^{\circ} \mathrm{C}$ for 60 minutes. The reaction was halted with $50 \mu \mathrm{L}$ of $2 \%(\mathrm{v} / \mathrm{v}) \mathrm{H}_{3} \mathrm{PO}_{4}$, plates were aspirated and washed two times with $200 \mu \mathrm{L} 0.9 \%(\mathrm{w} / \mathrm{v}) \mathrm{NaCl}$. Incorporation of ${ }^{33} \mathrm{Pi}$ was established with a microplate scintillation counter (Microbeta, Wallac). All assays were performed with a BeckmanCoulter/SAGIAN ${ }^{\mathrm{TM}}$ Core System.

$\mathrm{IC}_{50}$ values were measured by testing 10 concentrations $\left(1 \times 10^{-5} \mathrm{M}\right.$ to $\left.3 \times 10^{-10} \mathrm{M}\right)$ of each compound in singlicate. Residual activities for each concentration and the compound $\mathrm{IC}_{50}$ values 
were calculated using Quattro Workflow V3.1.1 (Quattro Research GmbH, Munich, Germany; www.quattro-research.com).

\subsection{Docking assay}

All molecular computation studies were carried out using Discovery Studio 2017 (Accelrys, San Diego, USA). The X-ray crystal structure of ALK5 complexed with 5,6-dihydro-4H-pyrrolo[1,2$b$ ]pyrazole inhibitor was obtained from protein data bank (PDB: 1RW8). The water molecules and heavy atom in protein were removed and the protein was prepared by adding hydrogen and correcting incomplete residues using Clean Protein tool of DS, then the protein was refined with CHARMm. The structures of $\mathbf{1 6 b}$ and $\mathbf{1 6 f}$ were sketched in 2D and converted into 3D using the DS molecule editor. Automated docking studies were carried out to investigate the binding mode of compound $\mathbf{1 6} \mathbf{b}$ and $\mathbf{1 6 f}$ in the crystal structure of 5,6-dihydro-4H-pyrrolo[1,2-b]pyrazole utilizing DSCDOCKER protocol. The pose with the top CDOCKER_INTERACTION_ENERGY was chosen for analyzing the binding features of compound $\mathbf{1 6 b}$ and $\mathbf{1 6 f}$ with ALK5.

\subsection{Prediction of ADMET properties}

ADMET properties of good targeted compounds $\mathbf{1 6} \mathbf{e}-\mathbf{h}$ as drug lead compound were predicted using ADMET descriptors in Discovery Studio 2017 (Accelrys, San Diego. USA). It is a quick, easy and accurate method for prediction of absorption, distribution, metabolism, elimination and toxicity (ADMET) properties. In this work, for the aforementioned compounds, human intestinal absorption level, aqueous solubility $(\log (\mathrm{SW}))$, blood brain barrier (BBB) penetration level (AlogP98), human cytochrome P450 2D6 (CYP2D6) inhibitory ability, hepatotoxicity possibility and plasma protein binding (PPB) level were measured.

\section{Conclusion}

In our study, three series of 3-substituted-4-(quinoxalin-6-yl) pyrazoles 14a-h, 15a-h, 16a-h, 22a, 22b, 22d, 23a, 23b, 23d, 24b, and 24d were synthesized and evaluated for ALK5 and p38 $\alpha$ MAP kinase inhibitory activities in enzymatic assays. We found that insertion of a 4-methylthiazol-2-yl moiety at the 3-position of the pyrazole ring was not as good as 6-methylpyridine, but these compounds significantly increased ALK5 inhibitory activity and selectivity. The most potent compound, 16f, inhibited ALK5 phosphorylation with an IC50 value of $0.28 \mu \mathrm{M}$ and showed $98 \%$ inhibition at $10 \mu \mathrm{M}$ in the enzymatic assay. The selectivity index of $\mathbf{1 6 f}$ against p38 $\alpha$ MAP kinase was $>35$, much higher than that of positive control compound 3 (4). The docking study described that compounds possessing 4-methylthazol-2-yl moiety was found to show better docking interaction than compounds possessing 6-(dimethylamino)pyridin-2-yl moiety on its active site. All good targeted compounds were subjected to ADMET prediction and the predicted ADMET parameters were within the acceptable range defined for human use. In particular, compound $\mathbf{1 6 f}$ was the most promising and it could be considered worthwhile lead compound worthy of further investigation.

Author Contributions: Li-Min Zhao and Zhen Guo are co-authors; they contributed equally to this work. All the authors have read and approved the final manuscript.

Fundings: This work was supported by the National Science Foundation of China (No. 81560557) and the Education Department of Jilin Province Scientific Research Fund Project (No. 2016-283).

Acknowledgments: We thank Susan R. Doctrow, PhD, from Liwen Bianji, Edanz Group China (www.liwenbianji.cn/ac), for editing the English text of a draft of this manuscript.

Conflicts of Interest: The authors declare on conflicts of interest.

\section{References}

1. Derynck, R.; Zhang, Y.E. Smad-dependent and Smad-independent pathways in TGF- $\beta$ family signaling. Nature. 2003, 425, 577-584. Doi: https://doi.org/10.1038/nature02006 
2. Lim, H.; Zhu, Y.Z. Role of transforming growth factor- $\beta$ in the progression of heart failure. Cell. Mol. Life Sci. 2006, 63, 2584-2596. Doi: https://doi.org/10.1007/s00018-006-6085-8

3. Gu, L.; Zhu, Y.J.; Yang, X.; Guo, Z.J.; Xu, W.B.; Tian, X.L. Effect of TGF- $\beta /$ Smad signaling pathway on lung myofibroblast differentiation. Acta. Pharmacol. Sin. 2007, 28, 382-391. Doi: https://doi.org/10.1111/j.17457254.2007.00468.x

4. Shek, F.W.; Benyon, R.C. How can transforming growth factor beta be targeted usefully to combat liver fibrosis? Eur. J. Gastroente rol Hepatol. 2004, 16, 123-126. Doi: https://doi.org/10.1097/00042737-20040200000001

5. Wang, W.; Koka, V.; Lan, H.Y. Transforming growth factor- $\beta$ and Smad signaling in kidney diseases: Review Article. Nephrology. 2005, 10, 48-56. Doi: https://doi.org/10.1111/j.1440-1797.2005.00334.x

6. Heldin, C.H.; Miyazono, K.; Ten Dijke, P. TGF-beta signaling from cell membrane to nucleus through SMAD proteins. Nature. 1997, 390, 465-471. Doi: https://doi.org/10.1038/37284

7. Dong, M.; Blobe, G.C. Role of transforming growth factor- $\beta$ in hematologic malignancies. Blood. 2006, 107, 4589-4596. Doi: https://doi.org/10.1182/blood-2005-10-4169

8. Bierie, B.; Moses, H.L. Tumor microenvironment: TGF- $\beta$ : the molecular Jekyll and Hyde of cancer. Nat. Rev. Cancer. 2006, 6, 506-520. Doi: https://doi.org/10.1038/nrc1926

9. Rane, S.G.; Lee, J.H.; Lin, H.M. Transforming growth factor- $\beta$ pathway: Role in pancreas development and pancreatic disease. Cytokine Growth Factor Rev. 2006, 17, 107-119. Doi: https://doi.org/10.1016/j.cytogfr.2005.09.003

10. Byfield, S.D.; Major, C.; Laping, N.J.; Roberts, A.B. SB-505124 is a selective inhibitor of transforming growth factor- $\beta$ type I receptors ALK4, ALK5, and ALK7. Mol. Pharmacol. 2004, 65, 744-752. Doi: https://doi.org/10.1124/mol.65.3.744

11. Uhl, M.; Aulwurm, S.; Wischhusen, J.; Weiler, M.; Ma, J.Y.; Almirez, R.; Mangadu, R.; Liu, Y.W.; Platten, M.; Herrlinger, U.; et al. SD-208, a novel transforming growth factor $\beta$ receptor I kinase inhibitor, inhibits growth and invasiveness and enhances immunogenicity of murine and human glioma cells in vitro and in vivo. Cancer Res. 2004, 64, 7954-7961. Doi: https://doi.org/10.1158/0008-5472.can-04-1013

12. Bueno, L.; De Alwis, D.P.; Pitou, C.; Yingling, J.; Lahn, M.; Glatt, S. Semi-mechanistic modeling of the tumor growth inhibitory effects of LY2157299, a new type I receptor TGF- $\beta$ kinase antagonist, in mice. Eur. J. Cancer. 2008, 44, 142-150. Doi: https://doi.org/10.1016/j.ejca.2007.10.008

13. Jin, C.H.; Krishnaiah, M.; Sreenu, D.; Subrahmanyam, V.B; Rao, K.S.; Lee, H.J.; Park, S.J.; Park, H.J.; Lee, K.; Sheen, Y.Y.; et al. Discovery of N-((4-([1,2,4]triazolo- [1,5-a]pyridin-6-yl)-5-(6-methylpyridin- 2-yl)- $1 H$ imidazol-2-yl)methyl)-2-fluoroaniline (EW-7197): A highly potent, selective, and orally bioavailable inhibitor of TGF- $\beta$ type I receptor kinase as cancer immunotherapeutic/antifibrotic agent. J. Med. Chem. 2014, 57, 4213-4238. Doi: https://doi.org/10.1021/jm500115w

14. Jin, C.H.; Sreenu, D.; Krishnaiah, M.; Subrahmanyam, V.B.; Rao, K.S.; Mohan, A.V.N.; Park, C.V.; Son, J.Y.; Son, D.H.; Park, H.J.; et al. Synthesis and biological evaluation of 1-substituted-3(5)- (6-methylpyridin-2yl)-4- (quinoxalin-6-yl)pyrzoles as transforming growth factor- $\beta$ type I receptor kinase inhibitors. Eur. J. Med. Chem. 2011a, 46, 3917-3925. Doi: https://doi.org/10.1016/j.ejmech.2011.05.063

15. Tojo, M.; Hamashima, Y.; Hanyu, A.; Kajimoto, T.; Saitoh, M.; Miyazono, K.; Node, M.; Imamura, T. The ALK-5 inhibitor A-83-01 inhibits Smad signaling and epithelial-to-mesenchymal transition by transforming growth factor- $\beta$. Cancer Sci. 2005, 96, 791-800. Doi: https://doi.org/10.1111/j.1349-7006.2005.00103.x

16. Dewang, P.M.; Kim, D.K. Synthesis and biological evaluation of 2-pyridyl-substituted pyrazoles and imidazoles as transforming growth factor- $\beta$ type I receptor kinase inhibitors. Bioorg. Med. Chem. Lett. 2010, 20, 4228-4232. Doi: https://doi.org/10.1016/j.bmcl.2010.05.032

17. Belveren, S.; Ali Dondas, H.; Ulger, M.; Poyraz, S.; Garcia, M.E.; Saperas, M.F.; Sansano, J.M. Synthesis of highly functionalized 2-(pyrrolidin-1-yl)thiazole frameworks with interesting antibacterial and antimycobacterial activity. Tetrahedron. 2017, 73, 6718-6727. Doi: https://doi.org/10.1016/j.tet.2017.10.007

18. Vale, N.; Correia-Branco, A.; Patricio, B.; Duarte, D.; Martel, F. In vitro studies on the inhibition of colon cancer by amino acid derivatives of bromothiazole. Bioorg. Med. Chem. Lett. 2017, 27, 3507-3510. Doi: https://doi.org/10.1016/j.bmcl.2017.05.073

19. Cui, G.; Jin, J.; Chen, H.; Cao, R.; Chen, X.; Xu, B. Synthesis and biological evaluation of pyrimidine derivatives as novel human Pin1 inhibitors. Bioorg. Med. Chem. 2018, 26, 2186-2197. Doi: https://doi.org/10.1016/j.bmc.2018.03.024 
20. Kang, I.J.; Hsu, S.J.; Yang, H.Y.; Yeh, T.K.; Lee, C.C.; Lee, Y.C.; Tian, Y.W.; Song, J.S.; Hsu, T.A.; Chao, Y.S.; Yueh, A.; Chern, J.H. A potent, selective, and orally bioavailable HCV NS5A inhibitor for treatment of hepatitis C virus: (s)-1-((R)-2-(cyclopropanecarboxamido)-2-phenylacetyl)- N-(4-phenylthiazol-2yl)pyrrolidine-2-carboxamide. J. Med. Chem. 2017, 60, 228-247. Doi: https://doi.org/10.1021/acs.jmedchem.6b00962

21. Kumar, S.; Aggarwal, R.; Kumar, V.; Sadana, R.; Patel, B.; Kaushik, P.; Kaushik, D. Solvent-free synthesis of bacillamide analogues as novel cytotoxic and anti-inflammatory agents. Eur. J. Med. Chem. 2016, 123, 718-726. Doi: https://doi.org/10.1016/j.ejmech.2016.07.033

22. Bueno, J.M.; Carda, M.; Crespo, B.; Cunat, A.C.; Cozar, C.; Leon, M.L.; Marco, J.A.; Roda, N.; Cervera, J.F.S. Design, synthesis and antimalarial evaluation of novel thiazole derivatives. Bioorg. Med. Chem. Lett. 2016, 26, 3938-3944. Doi: https://doi.org/10.1016/j.bmcl.2016.07.010

23. Tsukamoto, I.; Koshio, H.; Kuramochi, T.; Saitoh, C.; Inamura, H.Y.; Nozawa, C.K.; Yamamoto, E.; Yatsu, T.; Shimada, Y.; Sakamoto, S.; Tsukamoto, S. Synthesis and structure-activity relationships of amide derivatives of (4,4-difluoro-1,2,3,4-tetrahydro-5H- benzazepin-5- ylidene)acetic as selective arginine vasopressin $\mathrm{V}_{2}$ receptor agonists. Bioorg. Med. Chem. 2009, 17, 3130-3141. Doi: https://doi.org/10.1016/j.bmc.2009.03.001

24. Concepcion, P.M.; Ana, B.S.M.; Benedicto del, R.; Pelaez, R.; Caballero, E.; Medarde, M. A new family of quinolone and quinoxaline analogues of combretastatins. Bioorg. Med. Chem. Lett. 2004, 14, 3771-3774. Doi: https://doi.org/10.1016/j.bmcl.2004.04.098

25. Jin, C.H.; Krishnaiah, M.; Sreenu, D.; Rao, K.S.; Subrahmanyam, V.B.; Park, C.Y.; Son, J.Y.; Sheen, Y.Y.; Kim, D.K. Synthesis and biological evaluation of 1-substituted-3(5)-(6-methylpyridin- 2-yl)-4-(quinolin-6yl)pyrazoles as transforming growth factor- $\beta$ type I receptor kinase inhibitors. Bioorg. Med. Chem. 2011b, 19, 2633-2640. Doi: https://doi.org/10.1016/j.bmc.2011.03.008

26. Baraldi, P.G.; Preti, D.; Tabrizi, M.A.; Fruttarolo, F.; Saponaro, G.; Baraldi, S.; Romagnoli, R.; Moorman, A.R.; Gessi, S.; Varani, K.; Borea, P.A. N66[(Hetero)aryl/(cyclo)alkyl-carbamoyl- methoxy-phenyl]-(2chloro)-5'-N-ethylcarboxamido-adenosines: The first example of adenosine-related structures with potent agonist activity at the human $\mathrm{A}_{2 \mathrm{~B}}$ adenosine receptor. Bioorg. Med. Chem. 2007, 15, 2514-2527. Doi: https://doi.org/10.1016/j.bmc.2007.01.055

27. Zhang, L.; Li, H.; Zhu, Q.; Liu, J.; Chen, L.; Leng, Y.; Jiang, H.; Liu, H. Benzamide derivatives as dual-action hypoglycemic agents that inhibit glycogen phosphorylase and activate glucokinase. Bioorg. Med. Chem. 2009, 17, 7301-7312. Doi: https://doi.org/10.1016/j.bmc.2009.08.045

28. Subramanyam, C.; Wager, T.T. Novel compounds as casein kinase inhibitors. US Patent. 2011, 0, 098, 272 A1.

29. Eyers, P.A.; Craxton, M.; Morrice, N.; Cohen, P.; Goedert, M. Conversion of SB 203580-insensitive MAP kinase family members to drug-senstive forms by a single amino-acid substitution. Chem. Bio. 1998, 15, 321328. Doi: https://doi.org/10.1016/s1074-5521(98)90170-3

30. Wang, Z.C.; Qin, Y.J.; Wang, P.F.; Yang, Y.A.; Wen, Q.; Zhang, X.; Qiu, H.Y.; Duan, Y.T.; Wang, Y.T.; Sang, Y.L.; Zhu, H.L. Sulfonamides containing coumarin moieties selectively and potently inhibit carbonic anhydrases II and IX: Design, synthesis, inhibitory activity and 3D-QSAR analysis. Eur. J. Med. Chem. 2013, 66, 1-11. Doi: https://doi.org/10.1016/j.ejmech.2013.04.035

31. Gellibert, F.; Fouchet, M.H.; Nguyen, V.L.; Wang, R.; Krysa, G.; Gouvile, A.C.; Huet, S.; Dodic, N. Design of novel quinazoline deirivatives and related analogues as potent and selective ALK5 inhibitors. Bioorg. Med. Chem. Lett. 2009, 19, 2277-2281. Doi: https://doi.org/10.1016/j.bmcl.2009.02.087

32. Liu, Y.M.; Feng, Y.D.; Lu, X.; Nie, J.B.; Li, W.; Wang, L.N.; Tian, L.J.; Liu, Q.H. Isosteroidal alkaloids as potent dual-binding site inhibitors of both acetylcholinesterase and butyrylcholinesterase from the bulbs of Fritillaria walujewii. Eur. J. Med. Chem. 2017, 137, 280-291. Doi: https://doi.org/10.1016/j.ejmech.2017.06.007

33. Patel, T.S.; Vanparia, S.F.; Patel, U.H.; Dixit, R.B.; Chudasama, C.J.; Patel, B.D.; Dixit, B.C. Novel 2,3disubstituted quinazoline- 4(3)-one derived from amino acid linked sulphonamide as a potent malarial antifolates for DHFR inhibition. Eur. J. Med. Chem. 2017, 129, 251-265. Doi: https://doi.org/10.1016/j.jmech.2017.02.012 